\section{A Guide to State Programs for the Reclamation of Surface Mined Areas}

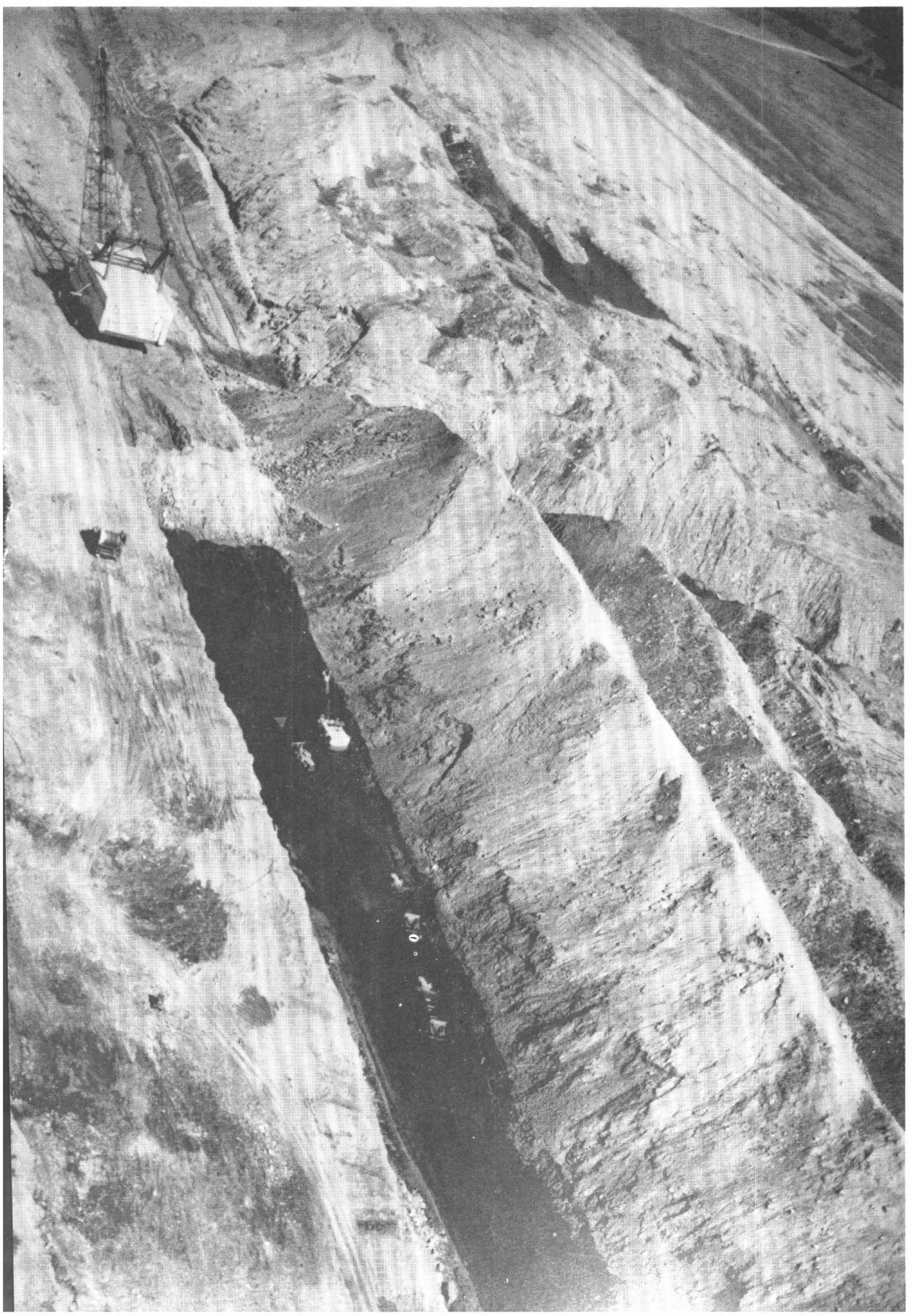

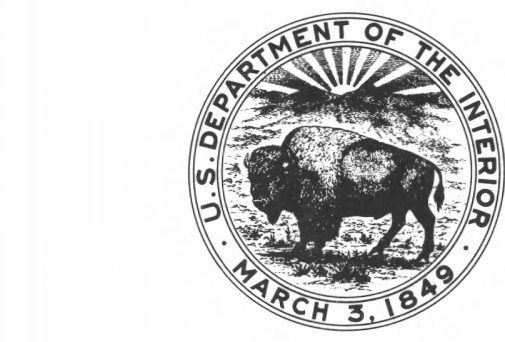

GEOLOGICAL SURVEY CIRCULAR 731

Resource and Land Investigations (RALI) Program 


\section{A Guide to State Programs for the Reclamation of Surface Mined Areas}

By Edgar A. Imhoff, Thomas O. Friz, and James R. LaFevers

\begin{tabular}{llll}
\hline GEOLOGICAL SURVEY CIRCULAR & 731
\end{tabular}

The status, content, and general trend of State programs for the reclamation of surface mined areas.

Resource and Land Investigations

(RALI) Program 
United States Department of the Interior

THOMAS S. KLEPPE, Secretary

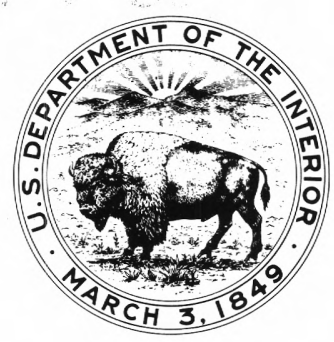

Geological Survey

V. E. McKelvey, Director

Library of Congress catalog-card No. 76-600011

Free on application to Branch of Distribution, U.S. Geological Survey 1200 South Eads Street, Arlington, Va. 22202 


\section{CONTENTS}

Glossary of selected terms

Abstract

Introduction

Sources of information -

Acknowledgments

A primer on surface mining and related reclamation -

Open pit mining

Quarrying

Pit mining

Area mining -_-_-_-_-_-_-_-_-_-

Contour mining -

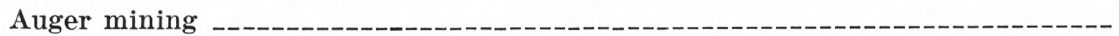

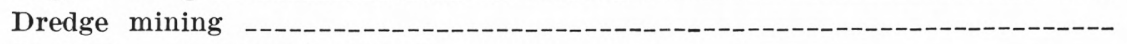

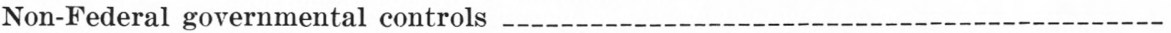

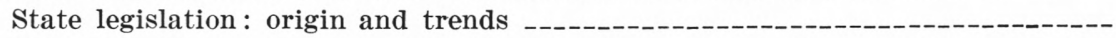

State and local controls

The matrix: approach and terms used

Matrix entries

Columns 2-4, stage of program development --_-_-

Columns 5-8, State law -

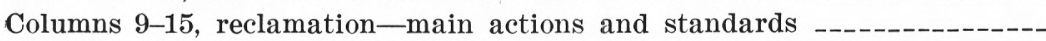

Columns 16-19, requirements for land-use planning ------------------

Columns 20-22, special provisions -

Column 23, substitute lands, and column 24, financial or economic analyses

The State programs: common threads, differences, and trends

Stages of development

The permit process

Mining method

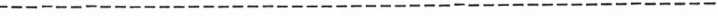

The doctrine of reasonableness --_-

Flexible interpretation of State laws -

Attention called to other laws --

The planning process

Conclusions

References cited -

A directory to State sources of information on surface mined-area reclamation programs, 1975

\section{ILLUSTRATIONS}

Figures 1-13. Photographs showing-

1. Open pit copper mine in Arizona near Tucson ---------

2. "Tailings" consisting of fine-grained rock products that have been transported by pipeline from a nearby site of copper-ore processing near Tucson, Arizona ------

3. Area of copper mine waste rock in Arizona reclaimed by the irrigation of introduced (nonnative) species of grasses, shrubs, and trees 
Figure 4. Limestone quarry in Wisconsin

5. Abandoned quarry which has been converted into a park for water-oriented recreation in Wisconsin

6. Sand and gravel pit in the Los Angeles area of California

7. Mined-out gravel pit converted to a prime residential area through grading, water control, and revegetation in Wisconsin

8. Area mine in Indiana showing soil removal underway, overburden removal by dragline, coal removal from floor of cut, and ungraded spoil ridges

9. Farmlands and ponds created through the reclamation of an area mine in Indiana

10. High-value residences in Indiana on lake occupying the "last cut" of an area mine

11. Results of head-of-hollow fill method of disposing of overburden and rock waste from a contour mine in West Virginia

12. Equipment used to drill laterally into a coalbed exposed in contour mining

13. Dredge mining for gold near Yuba City, California

14. Sketch of the concept of integrated mining, reclamation, and land-use planning

6

6

7

8

9

11

11

23

24

25

\section{TABLES}

TABLE

1. Matrix of information on State surface mined-area reclamation programs

Page

2. Hypothetical example of State and local controls and permits required for a surface mine

\section{GLOSSARY OF SELECTED. TERMS}

[These definitions of terms are generalized. Consequently, the definitions will probably not conform in detail to the "official" definitions of a State. Nor will one State's definitions-official or as used informally - necessarily equate with those of another State]

Area mining. A method of surface mining in lands of relatively gentle slopes and flat-lying bedrocks or mineral deposits through the digging of a succession of contiguous parallel pits. In a given pit or cut, overburden removed is cast (placed) in the minedout cut immediately adjacent.

Auger mining. The process of extracting coal at a cutface or highwall by drilling holes laterally into an exposed coalbed with a large-diameter auger type bit that delivers coal at the point of entry as the bit advances into the wall or face.

Backfill and grade. To place soil, overburden, or waste rock into a surface mine excavation and level or shape this fill material to a desired surface configuration.

Bench. (1) The surface of an excavated area at some point between the material being mined and the original surface of the ground on which equipment can move or operate; (2) A working road or base below a highwall as in contour mining for coal.

Box cut. A rectangular excavation made at the initiation of a surface mine by removing the overburden from bedrock so that essentially vertical walls result.
Contour mining. The general term for surface mining in steep terrain, in which overburden is removed and the mineral or rock is mined by cutting into a sloping land surface and then "following" the mineral or bedrock along a hillside with continuous excavations being made at approximately the same elevation.

Cutface. An unmined steep side of a pit, mine cut, or quarry.

Highwall. (1) The unexcavated face of exposed overburden and bedrock in a surface mine; (2) The face or bank on the uphill side of a contour mine.

Last cut. In area mining, the last linear excavation made as a result of which a highwall remains.

Original contour. The pre-mining surface configuration of the land, not necessarily the pre-mining elevation.

Overburden. Soil, rock, and other materials which overlie mineral deposits and are removed in surface mining.

Reclamation. The process of converting mined land to its former or other productive uses. (Modified from Bituminous Coal Research, Inc., 1974.)

Spoil. Overburden or mineral waste excavated and redeposited in surface mining. 
spoil ridge. A series of contiguous piles of spoil deposited adjacent and roughly parallel to the mine excavation.

spoil peak. The highest point of an individual spoil pile.

strike-off. To reduce the height and slope of spoil piles by mechanically truncating the peaks and smoothing out narrow ridges, generally with a motor grader or dozer.

jubsoil. The $B$ soil horizon or profile, or, in soils with weak profile development, the soil below the surface soil in which roots normally grow. (Modified from Bituminous Coal Research, Inc., 1974.)

jubstitute lands. Lands previously mined that are reclaimed in lieu of the reclamation of lands at the active or planned mine site.

Survival standards. Standards to measure the effectiveness of the revegetation phase of reclamation by the extent to which seeded or planted species become capable of self-regenerative growth (usually measured by percent of area having specific types of growing plants and the sizes of plant-devoid areas).
Terraced. Land that is cut or graded into a succession of gently sloping benches and steep inclines. Terrace types:

(a) Absorptive - a ridge type of terrace used primarily for moisture conservation;

(b) Bench-a horizontal or gently sloping terrace approximately on the contour, having a steep drop to the slope below ;

(c) drainage-a broad channel-type terrace used primarily to conduct water from the area at a low velocity; adapted to less absorptive soil and regions of high rainfall. (Modified from Bituminous Coal Research, Inc., 1974.)

Topsoil. The surface portion of the soil profile or overburden, which may be darkened by organic material; usually the most suitable medium for plant growth.

Toxic material. Any substance present in sufficient concentration or amount to injure plant or animal life. 



\title{
A Guide to State Programs for the Reclamation of Surface Mined Areas
}

\author{
By Edgar A. Imhoff, ${ }^{1}$ Thomas O. Friz, ${ }^{1}$ and James R. LaFevers ${ }^{2}$
}

\begin{abstract}
During 1975 inquiries of agencies in each State and review of State statutes and related administrative codes revealed that 38 States have established programs requiring the reclamation of surface mined lands. Results of analyses of those programs and ancillary data are presented in: (1) A table (matrix) which has been designed for the notation and elaboration of information pertaining to the mined-area reclamation programs of the 50 States; (2) a primer on surface mining activities and related reclamation practices and problems; and (3) a listing of types of non-Federal governmental controls applicable to reclamation. Interpretations of the status and content of State programs suggest that although a common thread runs through State statutory language, administrative requirements vary from state to State in order to meet different natural, economic, social, and political considerations. A general trend is seen in State programs toward the requiring of an integration of landuse planning and mine planning, with increased local governmental involvement.
\end{abstract}

\section{INTRODUCTION}

Reclamation of surface mined lands in the United States is a topic of considerable interest to envirommentalists, resource developers, energy suppliers, and ultimately, every citizen who enjoys the fuel, metals, chemicals, building materials, and increased agricultural productivity that result from such mining activities. In 1975 the Geological Survey, through the Department of the Interior Resource and Land Investigations program, interviewed agencies in the 50 States, in order to determine the existence, status, and general content of State regulatory programs which address the statutory objectives of reclamation of surface mined lands for long-term beneficial land use. Because of the increased interest during 1975 in energy and other resources within the United States, this report should be of interest and utility to land and resource planners, as well as to the

${ }^{1}$ U.S. Geological Survey, Reston, Virginia.

2 Argonne National Laboratory, Argonne, Illinois. administrators, technicians, and elected officials who are involved in decisions relating to resource development requiring surface mining and the subsequent reclamation of mined areas.

The number of State programs designed specifically for mined-area reclamation has increased from one in 1939, with the initial action of West Virginia, to 38 States in 1975. Thirty-two of the State programs became effective during 1970-75. In several of the remaining 12 States, draft legislation abounds and all 50 States are likely to have programs by 1980 .

If present legislative and administrative trends continue, mined-area programs of States will appear largely as separate responses to individually perceived needs. As this report will show, however, most of the programs now coming on line are directed toward increasing integration of the formerly separate activities of local public planning, private mining, and State-private reclamation. Resource managers and planners, private as well as public, are being called upon to join mine operators, engineers, and scientists in addressing the complex technical tasks required in an integration of land planning, mining, and reclamation.

The aim of this report is modest-it is intended to be a cursory display, analysis, and interpretation of the State programs for the reclamation of surface mine lands. Underground mining, lands underlying freshwater lakes, and submarine lands of the Continental Shelf are not covered. "Orphan" mined lands (lands mined but not reclaimed) are not discussed. State public land laws and Federal land and mineral laws receive only brief mention, and local planning considerations are treated in very cursory fashion. These omissions in coverage are due entirely to logistical considerations and should not be interpreted as rendering unimportant the omitted topics. 
There is no intention to indicate or present an overall judgment of the merit of the State role or to assess the effectiveness of the various State reclamation programs. Such undertakings would indeed require a very bold charter and a program familiarity far beyond that possessed by the authors.

\section{SOURCES OF INFORMATION}

The principal sources of information for this report consist of the printed laws, rules and regulations, and guidelines of the individual States, plus oral and written communications with many of the State mined-area reclamationists. ${ }^{3}$ State officials and agencies providing information are listed in the "Directory."

This report is also based on field visits by the authors to surface mining and reclamation sites in 27 of the 50 States.

\section{ACKNOWLEDGMENTS}

We acknowledge especially the many diligent skilled professionals in State governments who took precious time from actual mined-area reclamation activities to review and comment upon much of the information supporting this report. Any residual errors of fact and all interpretations are the responsibility of the authors.

A special acknowledgment is extended to Dr. Allen F. Agnew, Congressional Research Service, for his commentaries throughout the data collection and writing, and for his encouragement.

We thank the following employees of the U.S. Geological Survey for their technical review of the complete manuscript: Richard F. Hadley, William R. Keefer, and William Kockelman.

\section{A PRIMER ON SURFACE MINING AND RELATED RECLAMATION}

"In the early years of surface mining, major emphasis was placed on 'recovery of the mineral,' with little or no regard to 'recovery of the land.' Initial lack of concern for the environment caused increasingly stringent strip mine legislation. Reclamation has now become an integral part of most surface mining operations, and has caused some major revisions in mining techniques, particularly in the East. Current practice is to incorporate reclamation with the mining sequence, and not to regard it as a separate operation." (Skelly and Loy, Engineers and Consultants, 1975, p. 2-5.)

\footnotetext{
${ }^{3}$ A term adopted informally by State regulatory personnel to describe the function of administering a program for the conversion of mined lands to productive use.
}

Resource and land-use planning practices can be enhanced through awareness of the importance and nature of surface mining and related minedarea reclamation. As reported by Paone and others $(1974$, p. 7$), 86$ percent of the crude ore handled by the U.S. mining industry in 1971 came from surface mines. This included all the sand and gravel and phosphate, 98 percent of the clay, 96 percent of the stone, 94 percent of the iron ore, 90 percent of the copper, and 51 percent of the coal. From 1930 through 1971, land utilized in surface mining included $2,170,000$ acres $(870,000$ hectares) for mine excavations, 733,000 acres (293,000 hectares) for overburden and waste rock

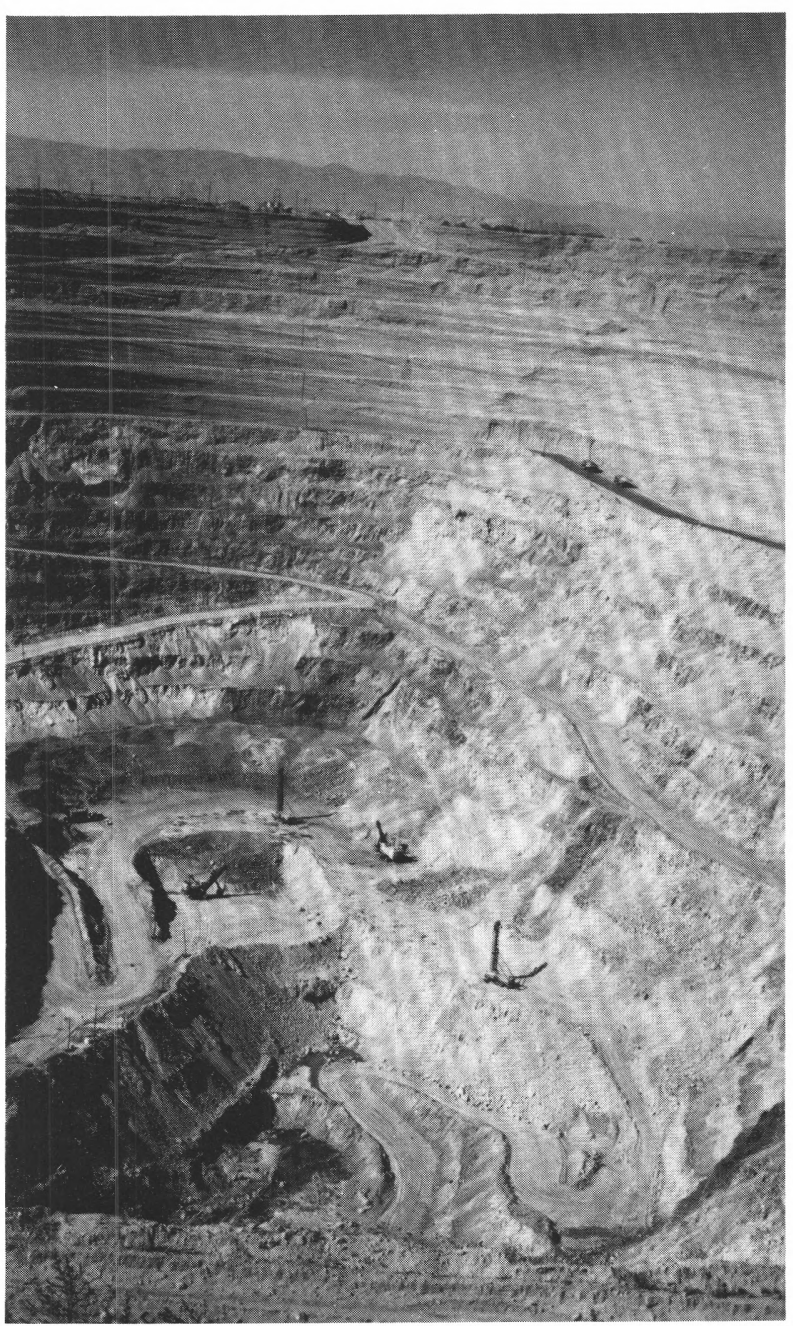

Frgure 1.-Open pit copper mine in Arizona, near Tucson. Vertical scale is indicated by the 60-foot masts of two drill rigs on bench in center foreground. More than 99 percent of the material removed from this open pit has been deposited on nearby lands. 
disposal, and 454,000 acres (182,000 hectares) for process waste and tailings. Of the $3,357,000$ total acres $(1,343,000$ hectares)disturbed over this period, 1,436,000 acres $(574,000$ hectares) were reclaimed. The unreclaimed acreages represent active open pits and quarries and strip mines operated before the advent of State mined-area reclamation laws.

The variety of State mining laws and regulations shown in table 1 covers all the surface mining methods now in use in the United States, with the possible exception of subaqueous coastal zone mining. ${ }^{4}$ The major methods are open pit, quarry, pit, area, contour, auger, and dredge mining. A brief description of each of these mining methods is included to define the method, point out basic characteristics, and show the wide range of surface disturbance that can occur. Basic mined-area reclamation techniques and associated constraints are also presented.

${ }^{4}$ Grant (1973) describes ocean mining methods and outlines the status and content of State regulations on mining (petroleum excluded) on the Continental Shelf.

\section{OPEN PIT MINING}

Open pit or open cut mines (fig. 1) are used primarily to extract metallic minerals from nearsurface ore bodies. These mines tend to be deepsome in excess of 1,000 feet (305 metres). Mining usually continues uninterrupted for many years and produces large amounts of waste rock and "tailings," the term for the finely ground waste rock and chemically leached material from which valuable minerals have been extracted.

Reclamation of open pit mines is difficult because of the constraints represented by : (1) Large volumes of wastes (up to 99 percent of material mined in copper mines is waste) ; (2) sharp differences in physical and chemical characteristics of wastes from the same pit; and (3) the deep excavation left when mining is concluded. Large acreages of land-sometimes hundreds of acres per mine-are used for waste disposal. Reclamation of tailing ponds is difficult because of the fine-grained nature of the waste, which tends to become windblown when dry and physically unstable when wet. Because of textural and chemical problems, tailings (fig. 2) are difficult to revege-

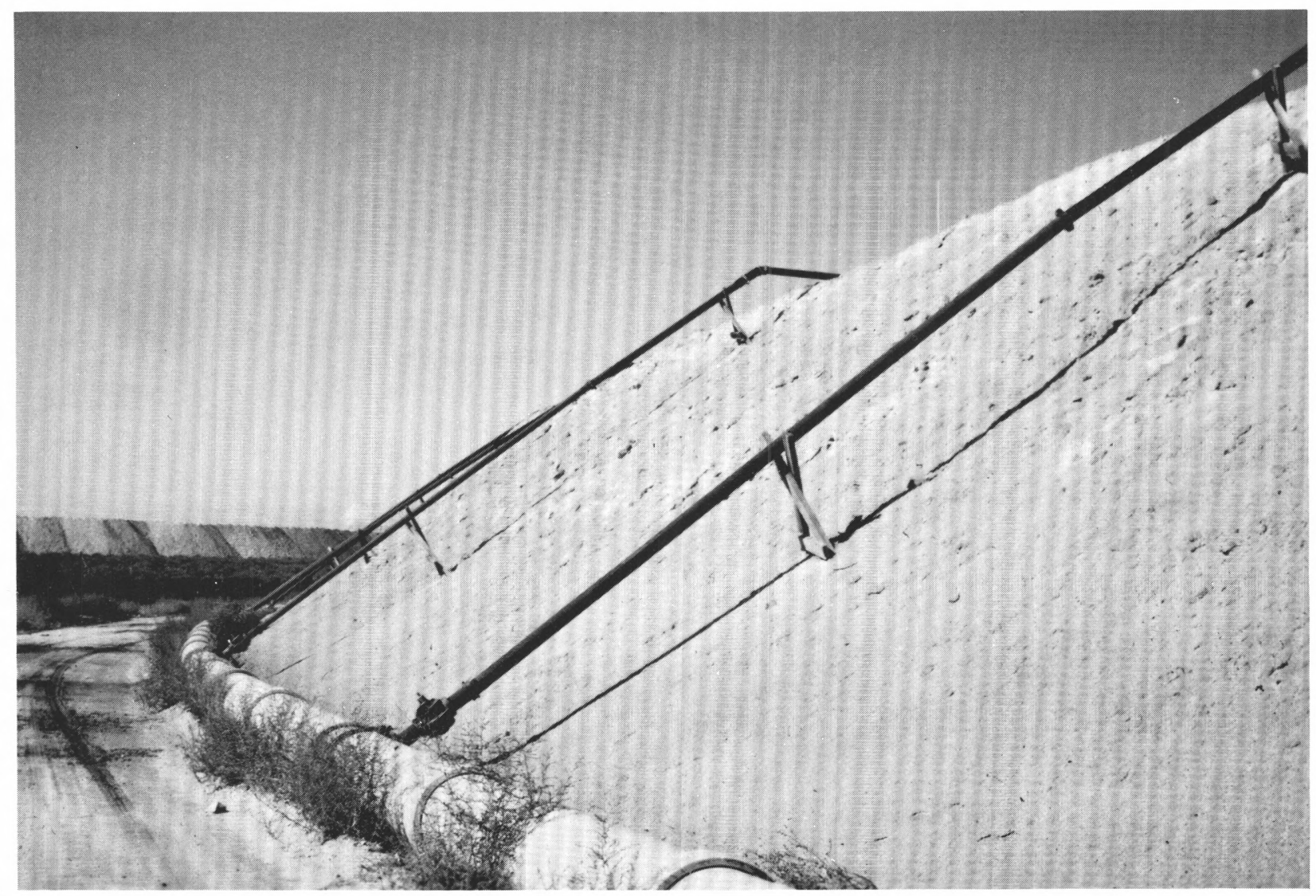

Figure 2.- "Tailings" consisting of fine-grained rock products that have been transported by pipeline from a nearby site of copper-ore processing near Tucson, Arizona. Reclamation of tailings is still in experimental stages. 
tate. As indicated in figure 3, revegetation has been accomplished on some of the wastes from open pit mines. Coarse rock wastes are sometimes used as aggregate, and overburden has been used for agriculture. A study team at the University of Arizona (Matter and others, 1974) designed comprehensive plan alternatives (using scale models) for open pit copper mines and mine waste disposal areas. Zube (1963) suggested land uses and landscape design principles for the reclamation of taconite areas in Wisconsin. Active open pits, as compared to area coal mines, provide fewer opportunities for simultaneous mining and reclamation because of inherent conflicts in land use that prevail as long as mining is underway. When mining ceases, the problem of sequential use of the pit is tied primarily to economic feasibility.

\section{QUARRYING}

Quarries are used to extract stone for ornamental and building purposes or as a source of

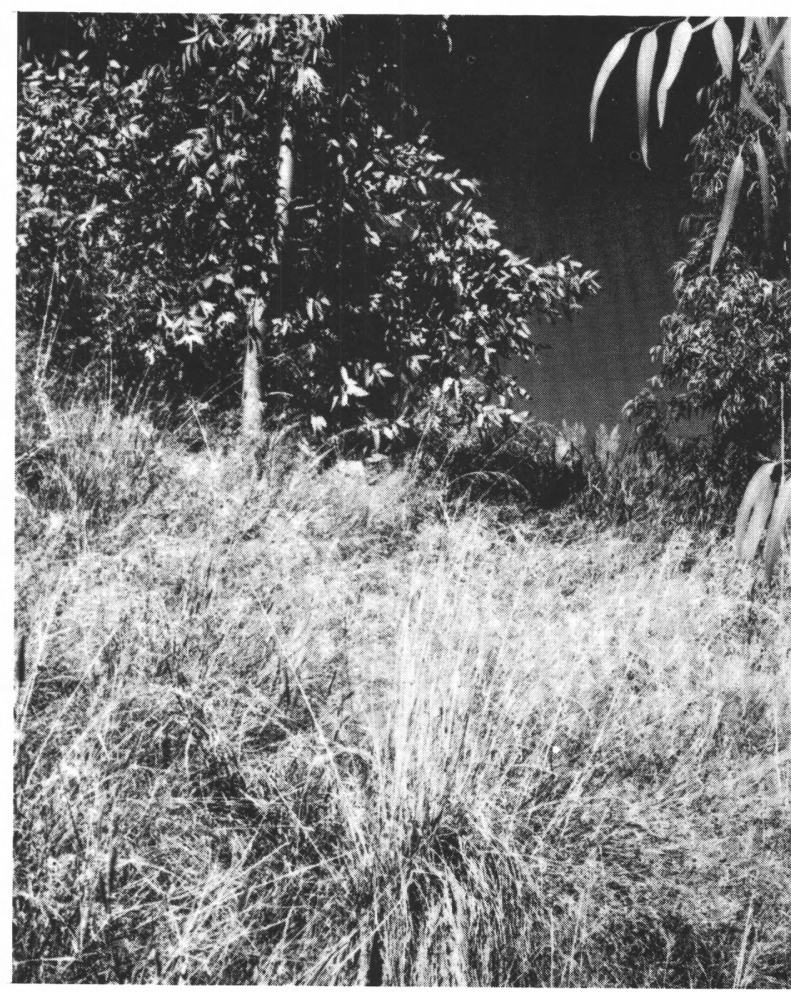

Figure 3.-Reclamation of copper mine waste rock in Arizona has been accompanied by the irrigation of introduced (nonnative) species of grasses, shrubs, and trees. crushed stone for construction materials or chemicals. Quarries vary considerably in size and depth, depending upon the quality, use, and physical characteristics of the rock mined (fig. 4). Quarries generally are not as deep as open pit mines, although depths to 200 feet (61 metres) are not uncommon. Normally, quarries are active for extended periods of time, some operations continuing for more than 100 years. Waste rock production from quarries is small, and therefore surface disposal of waste is usually not a serious problem. Reclamation of a quarry site commonly is difficult because of steep sides, great depths, and lack of drainage. Recreation (fig. 5) is probably the most common reclamation objective. An imaginative reclamation plan was prepared by Angster and others (1970) for the eventual conversion of a crushed stone quarry to a site for an apartment complex.

\section{PIT MINING}

Pits are the most common type of excavation for sand, gravel, or clay. They tend to be shallow-rarely exceeding 100 feet (30 metres) in depth--and generally have limited surface extent (fig. 6). The large number of pits is the result of the high demand for sand and gravel and the relatively small volume of these materials normally in any one deposit. Most communities are served by one or more sand and gravel pit. Clay pits are dug less frequently than sand and gravel pits but are nonetheless numerous. Relatively little waste is produced by pit mining. Unmarketable overburden or other materials may be bypassed during mining or returned to the pit after processing. The extent of reclamation of pits varies rather directly according to the nearness of urban communities. Urban lands are generally valuable, and reclamation of pits for planned sequential use is often required by local units of government. In the Midwestern United. States many pits have been reclaimed for water-oriented residential development (fig. 7).

\section{AREA MINING}

Area mining is used to extract near-surface bedded deposits in flat-lying terrain. Coal and coastal plain phosphate are most commonly extracted using area mining methods. The overburden is removed from the first cut, followed by removal of the mineral material. A second paral- 


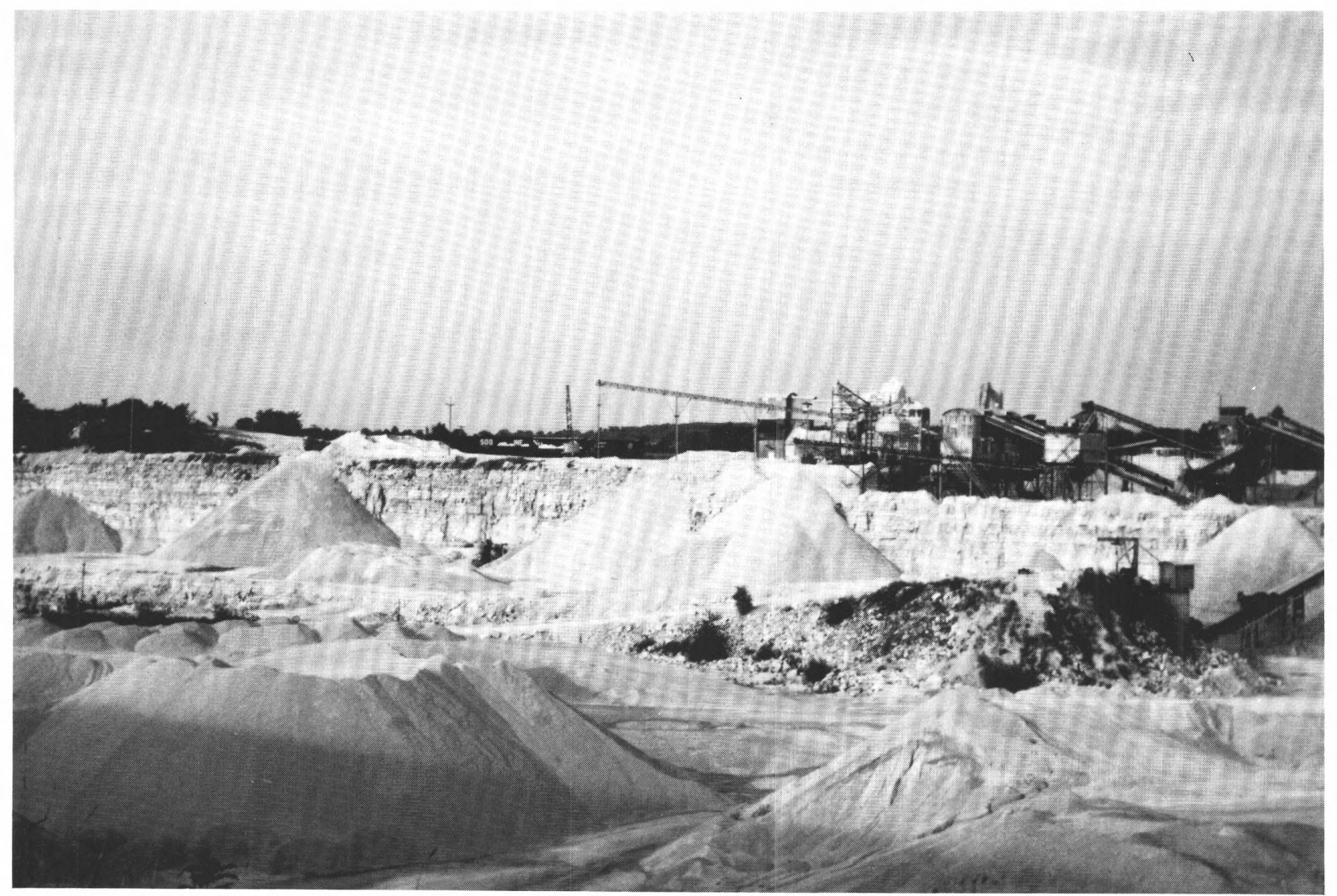

Figure 4.-Limestone quarry in Wisconsin. The life of a quarry usually spans many years, with significant reclamation possible only after final shutdown.

lel cut is then made, and the overburden removed is placed into the pit resulting from the first cut. The series of parallel cuts progresses across the property until the depth of overburden and coal characteristics make the mine uneconomic or until property boundaries are reached. Some area mines now reach depths of 200 feet (61 metres). Large tracts of land tend to be disturbed by area mining, but only a narrow tract of land is unreclaimed at any given time. Figure 8 shows a mine in which grading or levelling of spoil has taken place only two ridges away from an active mine cut. Area mines reclaimed for agricultural, residential, and recreational purposes are shown in figures 9 and 10.

\section{CONTOUR MINING}

Contour mining is used principally to extract coal that crops out along the sides of steep hills, the mine following the coal seam around the hill- side. The overburden above the coal is removed, followed by the coal. Overburden up to 150 feet deep (46 metres) can be handled-depending on coal thickness and quality. Auger mining may be used to extract additional coal from the coal seam exposed in the highwall. Handling of overburden creates problems in contour mining because of the little working space available. Historically, reclamation involved casting the overburden down hill slopes. Modern practice emphasizes replacing overburden in the contour mine immediately after coal removal. Mountaintop mining is a variation of both contour and area mining. Some of the overburden removed to expose the coal is placed in head-of-hollow fills (fig. 11), and the remaining overburden is placed in the previous cuts. The entire coal seam is mined progressively, as in area mining. Grading of the spoil creates flat to gently rolling topography which can support a variety of sequential land uses. 


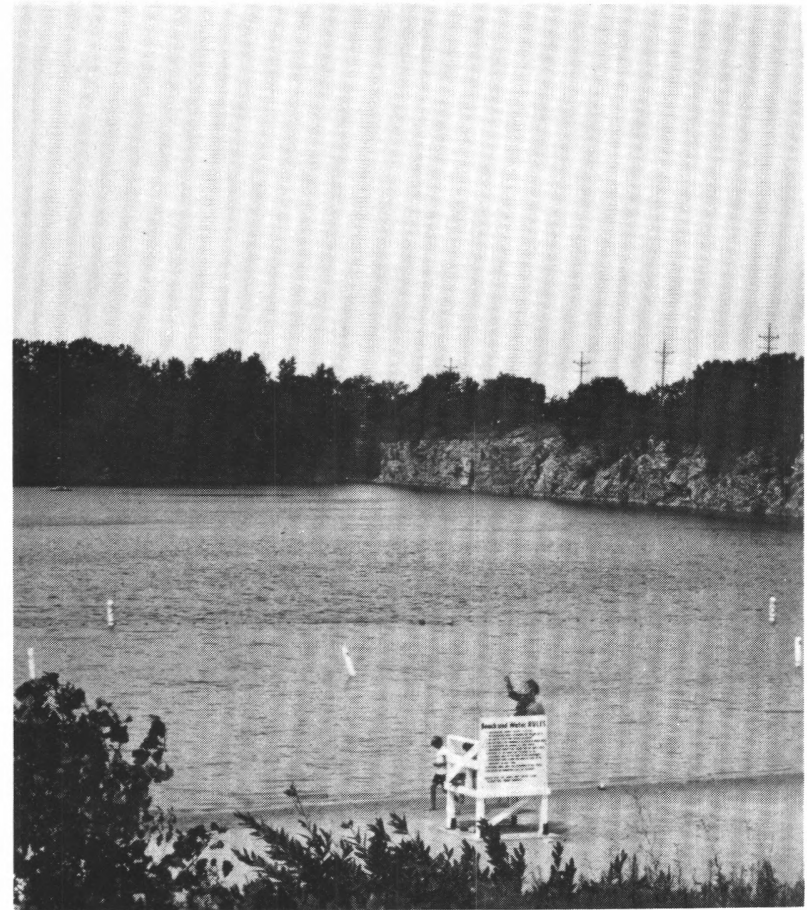

Figure 5.-Abandoned quarry which has been converted into a park for water-oriented recreation, Wisconsin.

\section{AUGER MINING}

Auger mining utilizes auger drills several feet in diameter that can penetrate several hundred feet (usually in a horizontal direction) into a coal seam and extract the coal. Auger mining is used commonly with contour mining to recover additional reserves of coal from the bank or highwall (fig. 12). When the overburden becomes too thick to allow economical contour stripping to continue and underground mining would be uneconomical or hazardous, an auger is used to remove additional coal.

Auger mining requires that the last strip cut be left open for access of equipment and removal of the coal. Thus the final reclamation of the contour mine must be delayed until extraction of coal by the auger is complete.

\section{DREDGE MINING}

Dredge mining involves the continuous removal and processing of unconsolidated mineral deposits. The dredge is basically a floating platform (fig. 13) containing continuous digging or suction equipment to extract the mineral and processing equipment to segregate and remove the valuable

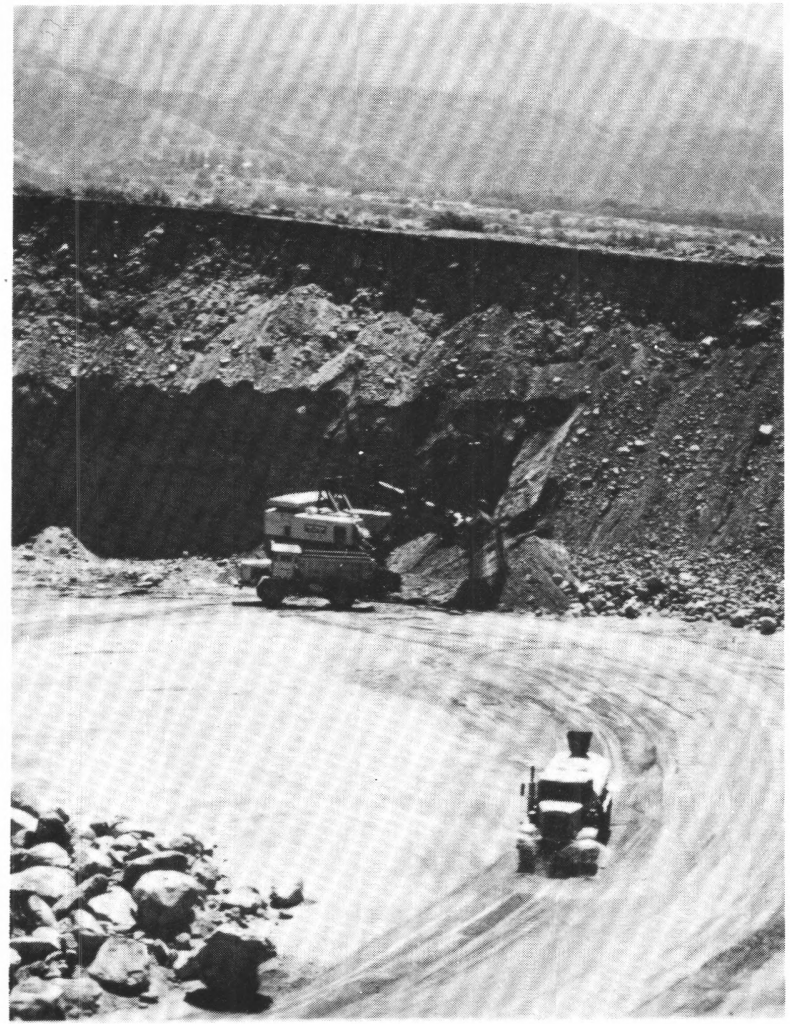

Figure 6.-Sand and gravel pit in Los Angeles area of California. Reclamation of sand and gravel pits in urban areas is facilitated by high land values.

mineral fraction. Dredges are used in the United States to mine sand and gravel deposits and placer gold deposits where water is available to float a dredge. Dredges are limited to digging depths of about 120 feet (36 metres). Dredging of sand and gravel results commonly in creation of a lake, as most of the excavated material is removed for sale. Dredging for gold, however, results in removal of but a minute portion of the material handled by the dredge. Waste disposal and subsequent reclamation of gold-dredged land is a considerable problem because waste material from gold dredging is stacked behind the dredge, creating spoil piles not unlike those of area mining. Reclamation of this waste is difficult because of the gravelly nature of the waste, lack of topsoil to re-establish plant growth after mining, and potential for flooding due to the location of most dredging operations in stream beds and valley floors. 


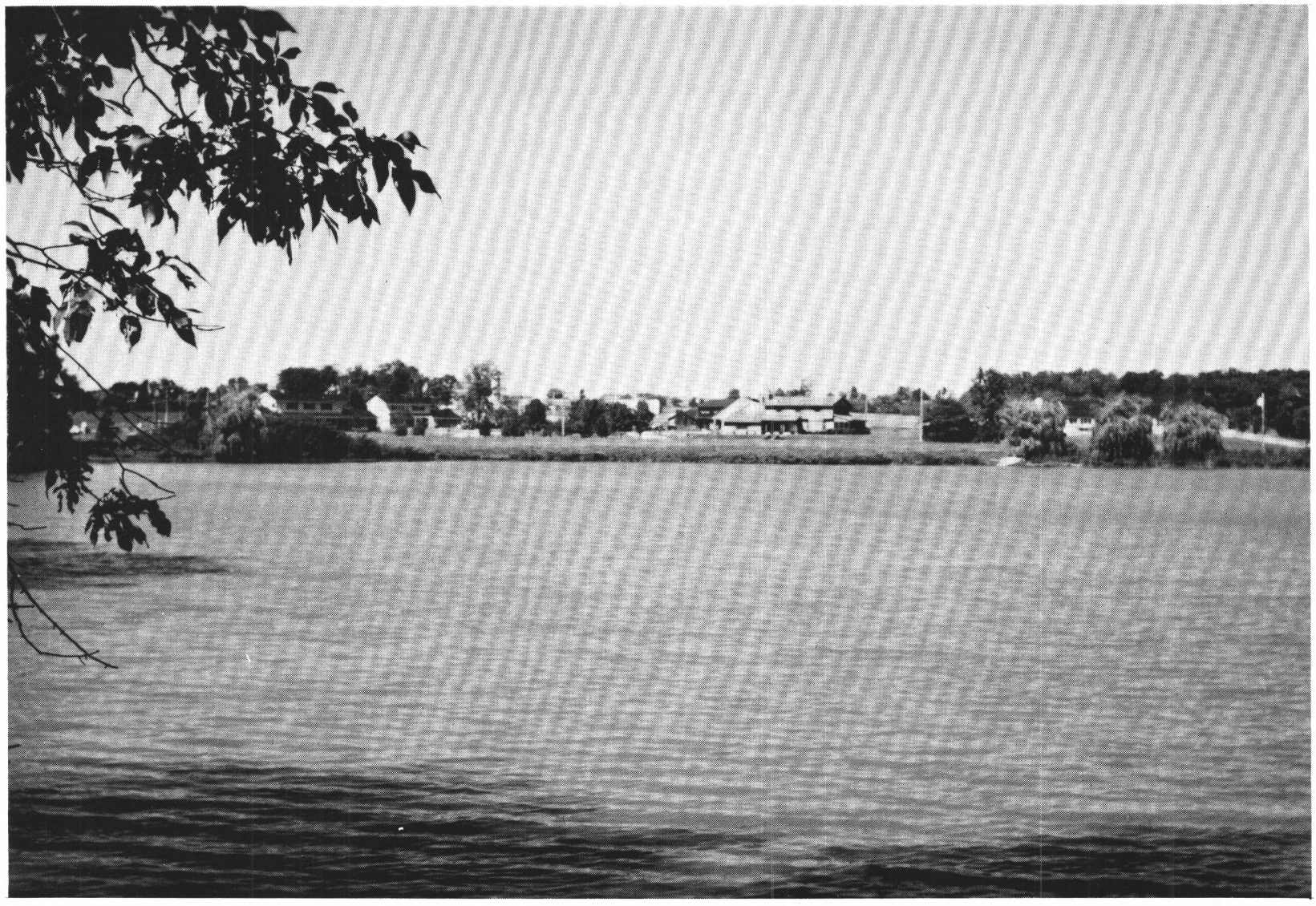

FIgURE 7.-Mined-out gravel pit converted to prime residential area through grading, water control, and revegetation in Wisconsin.

\section{NON-FEDERAL GOVERNMENTAL CONTROLS}

\section{STATE LEGISLATION: ORIGIN AND TRENDS}

The reclamation of surface mined lands in the United States began in the Midwest in the 1920's as a voluntary experimental program initiated by coal companies attempting to establish, at minimum costs, quick-growth forests on ungraded spoil heaps (Carter and others, 1974). Successful reforestation was demonstrated in West Virginia and was followed in Indiana by the successful conversion of strip mined land to pasture and to row crops at Meadowlark farms, near Terre Haute. The demonstration of reclamation capability and of the potential for recovery of costs (if not profit) provided substantial impetus for the first State mined-land reclamation laws, enacted in West Virginia in 1939, Illinois in 1943, Indiana in 1941, Pennsylvania in 1945, Ohio in 1947, and Kentucky in 1954.
Early State reclamation laws addressed only coal mining. Rules were promulgated requiring revegetation and, in some cases, reduction of spoil pile slopes as a means of converting strip mined land to a land-cover type that would be of economic value and would reduce erosion.

In the 1950's and 1960's, revisions in the early laws and the new laws of additional States normally added requirements for soil conservation and for water quality control at the site (an objective addressed also by intensified activities in Federal and State pollution control laws).

Near the close of the 1960 's, States began expanding coverage of the law to all minerals, and the new State laws tended to address land-use planning relationships to reclamation. Detailed standards were developed relating to all the major activities that occur at a mine site-before, during, and after mineral removal-and to the impact of the mining and reclamation activity on the surrounding environment. 


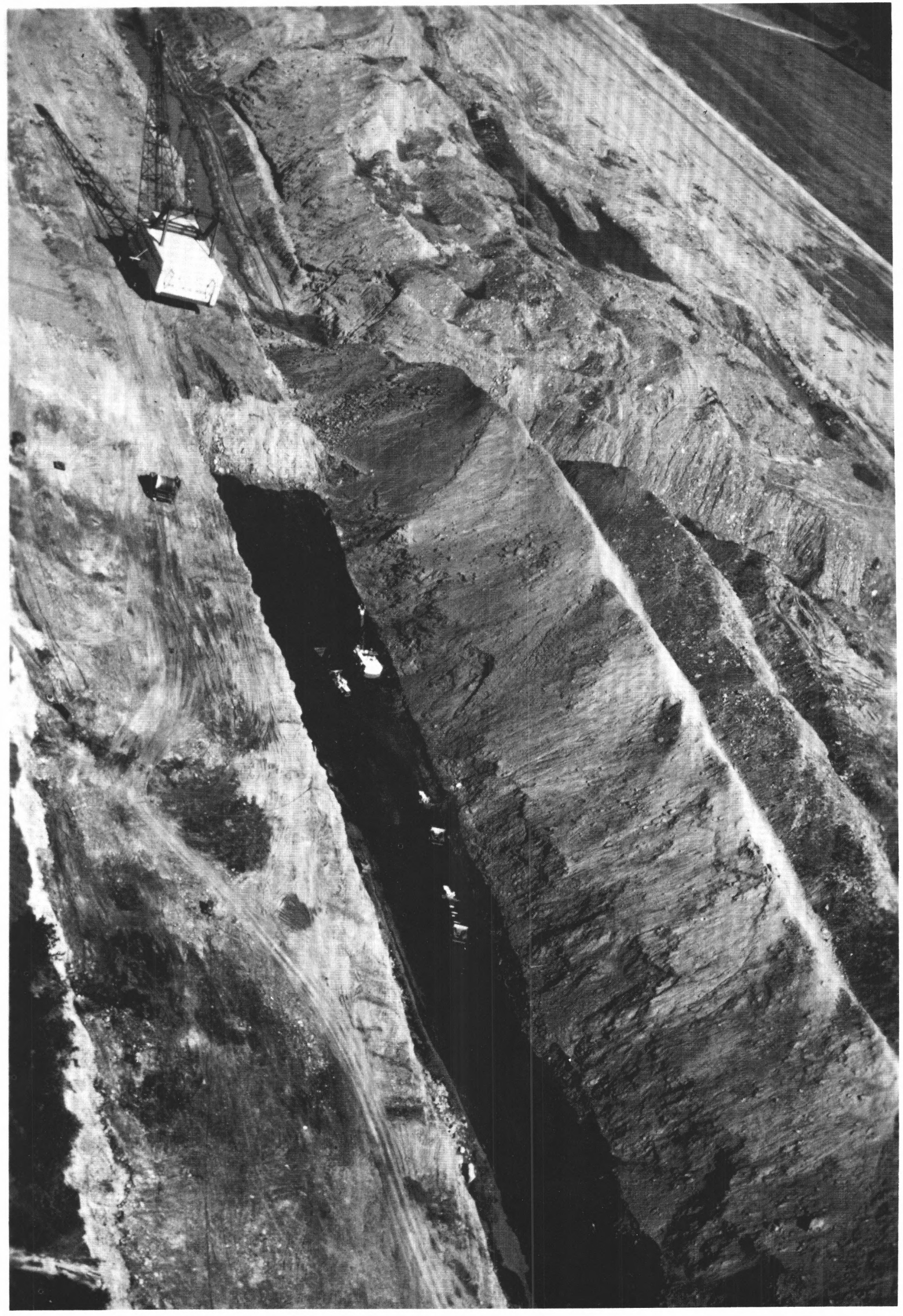




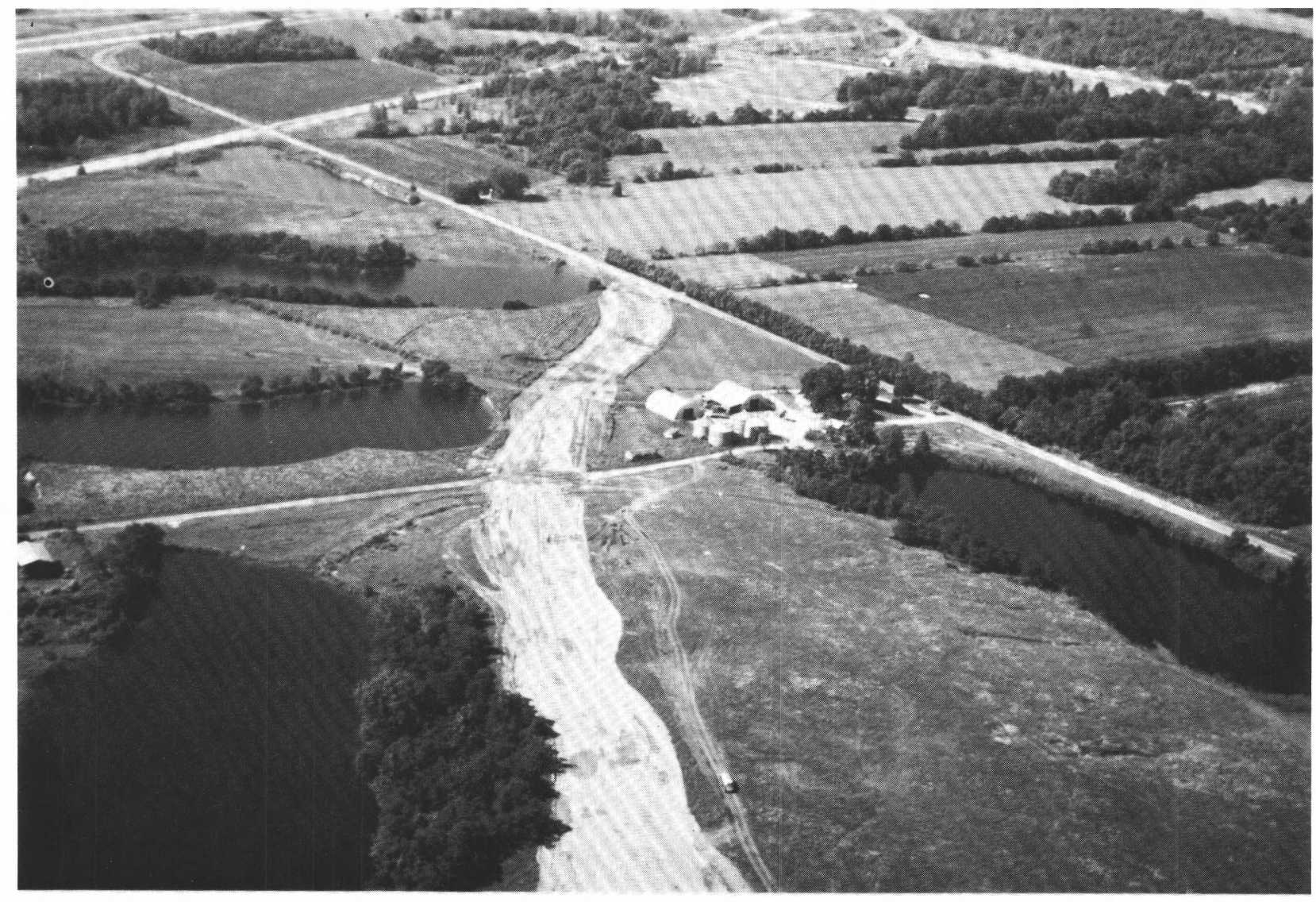

FIGURE 9.-Farmlands and ponds created through the reclamation of area mine in Indiana. Techniques for such reclamation were developed during the 1930 's.

The decade of the 1970's has been characterized by new programs that treat mining as an interim land use. This emerging concept, illustrated in figure 14, is being expressed increasingly in State legislation.

\section{STATE AND LOCAL CONTROLS}

Besides the governmental programs specifically termed "mined-area reclamation," a great number of other local and State controls of various kinds pertain to the integrated set of activities that occur over time at the "average" surface mine site. The number and type of controls vary by locale and by State. The hypothetical example given in table 2 suggests that the mine operator may have to obtain literally dozens of governmental permits (excluding Federal) if the mining, reclamation, and land-use activities that ensue at the site are to be lawful. Table 2 is based on a review of State and local legislation, State and local plans, and environmental impacts statements. See also Bisselle and others (1975, p. IV-22.).

\section{THE MATRIX: APPROACH AND TERMS USED}

A matrix of 24 items by 50 items (table 1 ) is the focal point of this report. The following text explains the rationale of the matrix and establishes the meaning of the terms used in subtitles and in column headings.

4 Figure 8.-Area mine in Indiana showing soil removal underway on left, overburden removal by dragline in background, coal removal from floor of cut in the center, and ungraded spoil ridges in the right foreground. Cut is about 60 feet (18 metres) deep. Area in upper right is reclaimed land mined 1 to 2 years before. 


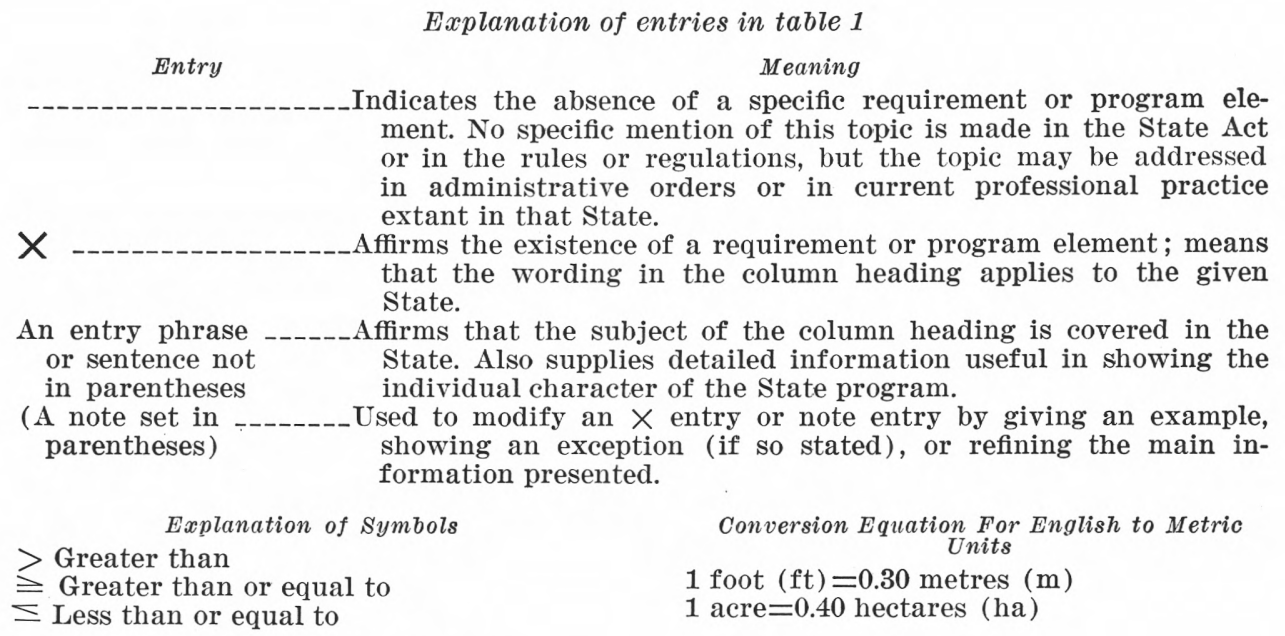

Definition of Technical Terms

See "Glossary", page IV.

Special Note on Heading of Column 21

The provision cited is a possible pre-application, blanket exclusion of surface mining from areas declared "off limits" on the basis of explicit criteria.

\section{MATRIX ENTRIES}

All 50 States are listed in the matrix even though there are no entries or notations under some column headings. Blank spaces signify the absence in a given State of a regulatory program for the reclamation of surface mined areas pertaining to all lands within a State. Where State laws on mined-area reclamation cover only certain lands (for example, Arizona), this is indicated by a note across the columns. Several States require reclamation of State-owned lands. Some States (e.g., Rhode Island) have little State-owned land open to mining, but local land-use control processes address mineral extraction. In addition, proposed Federal rules for reclamation apply in the States that have Federal lands open to mining. ${ }^{5}$ This report, however, concentrates upon the specifically named programs that apply mined-area reclamation laws to the total area of a State.

\section{COLUMNS 2-4, STATE OF PROGRAM DEVELOPMENT}

The sequence of the headings 2 through 4 follows the normal order of progression of State legislation and follow-up administrative action, deliberately omitting a bill phase. At any given time, some States are initiating new programs and other States are revising existing programs. The heading $A c t(s)$ refers to the existence of a legis-

5 For example, see Coal Mining Operating Regulations, 43 CFR Parts 23, 3040 and 30 CFR Parts 211, 216, p. 41122-
41139, Federal Register, vol. 40, no. 173, 9-5-75. lative mandate establishing a mined-area reclamation program for the whole State. Note that $\operatorname{Act}(s)$ does not refer to other State legislation that may be important to the successful establishment and conduct of a mined-area reclamation program-such as constitutional amendments, enabling legislation, administrative codes, and pollution control laws.

Rules and Regulations refers to the promulgation, by the authority stipulated in the Act, of requirements giving specific direction and setting minimum levels of performance. In practice, rules and regulations grade into "technical guidelines" - a term which in strict definition means instructional material. In this report, however, guidelines includes both standards and instructional materials, whether mandatory or recommendatory.

\section{GOLUMNS 5-8, STATE LAW}

Tittle of Act(s) refers to the official name, or statutory citation, of the State mined-area reclamation program. Governmental reorganization and statutory amendments may have changed the administrative agency and the Act from that originally cited. Administering Agency is the department of State government presently assigned the staff work of developing information, processing applications, and issuing and monitoring permits for mining and related reclamation.

Mineral or Commodity Covered and Rules (that) Vary By Mining Methods refer to the gen- 


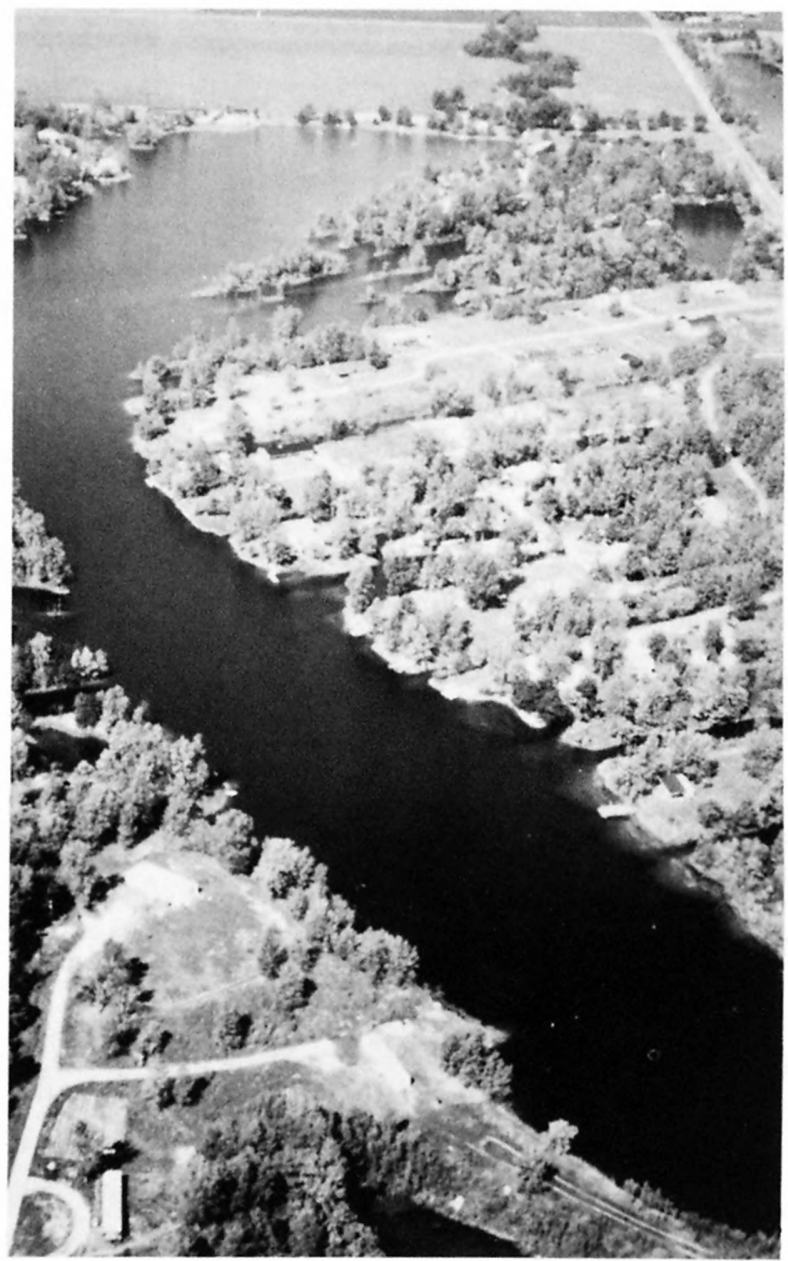

Frgure 10.-High-value residences in Indiana on a lake occupying the "last cut" of an area mine. Streets trend along the crest of ridges of spoil graded moderately to remove peaks.

eral coverage of the Act. In this report the terms "mineral" and "commodity" are used interchangeably to refer to essentially solid natural substances occurring in the earth and sought for commercial purposes. Natural gases, liquid petroleum, and water are excluded. The heading of column 8 addresses the fact that rules and regulations may differ according to the type of mining operation. An entry in column 8 usually necessitates entries in subsequent columns to note the nature of the variances.

\section{COLUMNS 9-15, RECLAMATION-MAIN ACTIONS AND STANDARDS}

These column headings give, generally, the sequence of major actions in mined-area reclamation. The wording is in popular but by no means

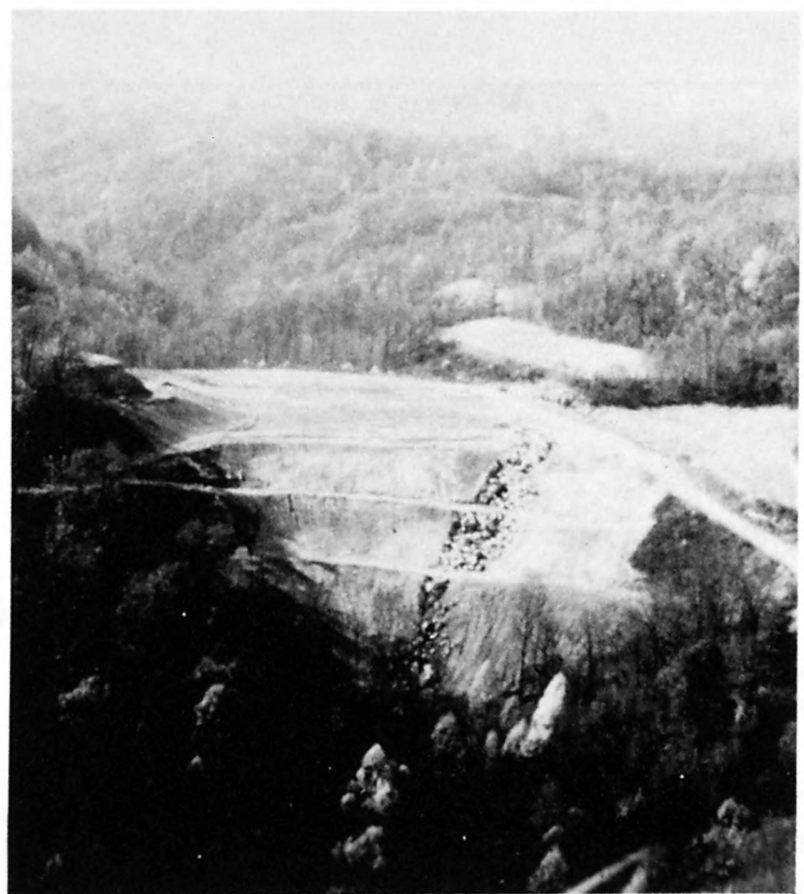

Figure 11.-Results of head-of-hollow fill method of disposing of overburden and rock waste from contour mine, West Virginia. Fill has been terraced to reduce slope. A rock gutter (center foreground) has been constructed to control runoff.

universal terms. The following partial listing of synonymous phrases is presented to help explain the headings. Specific terms are defined in the "Glossary."

\section{Column and heading Synonymous phrases}

(9) Control water flow and quality _._-_Institute water management.

Follow good soil and water conservation practices.

Secure adequate drainage and meet water pollution control standards.

(10) Conserve and replace topsoil _._-Segregate and re-spread topsoil.

Stockpile and re-use soils.

Remove and re-apply most suitable plantgrowth materials. 
TABLE 1.-Matrix of information on State surface - mined-area reclamation programs, December 1975

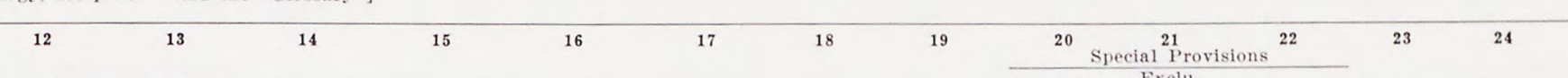

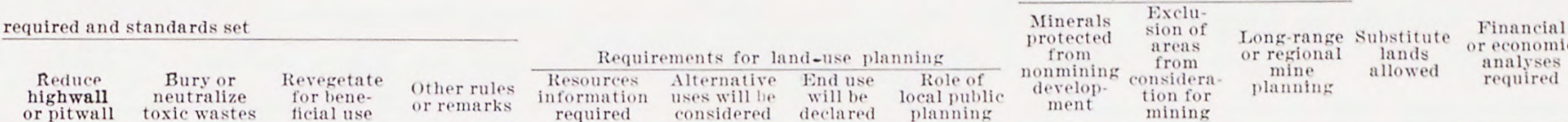

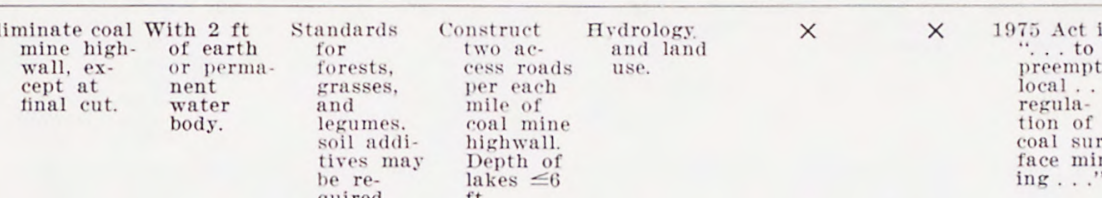

of leases to mine operators. Most of the mineral deposits of Alaska lie on State or Federal lands (where reclamation requirements are ALASKA NOTE: On State lands, reclamation requirements are established by the State of Alaska-on a case-by-case basis-as part of the termis
a condition of leasing).

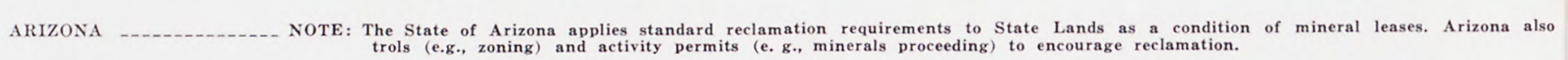

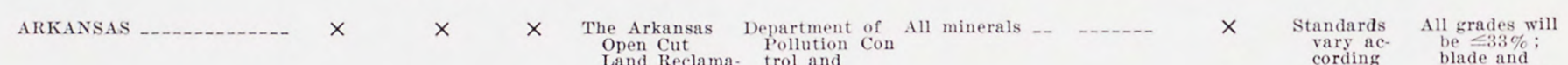
Land Reclama- trol and
tion Act of
1971. CALIFORNIA -

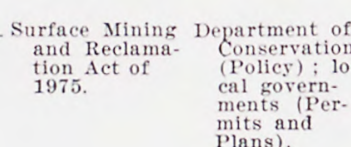

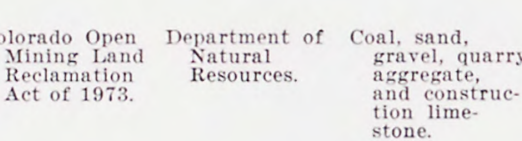

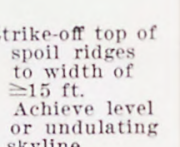

CONNECTICUT

DELAWARE

GEORGIA

HAWAII -

IDAHO

ILLINors

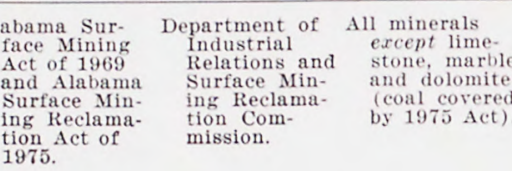

$\mathrm{x}$

With 3
of ex
or p p
nent

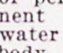

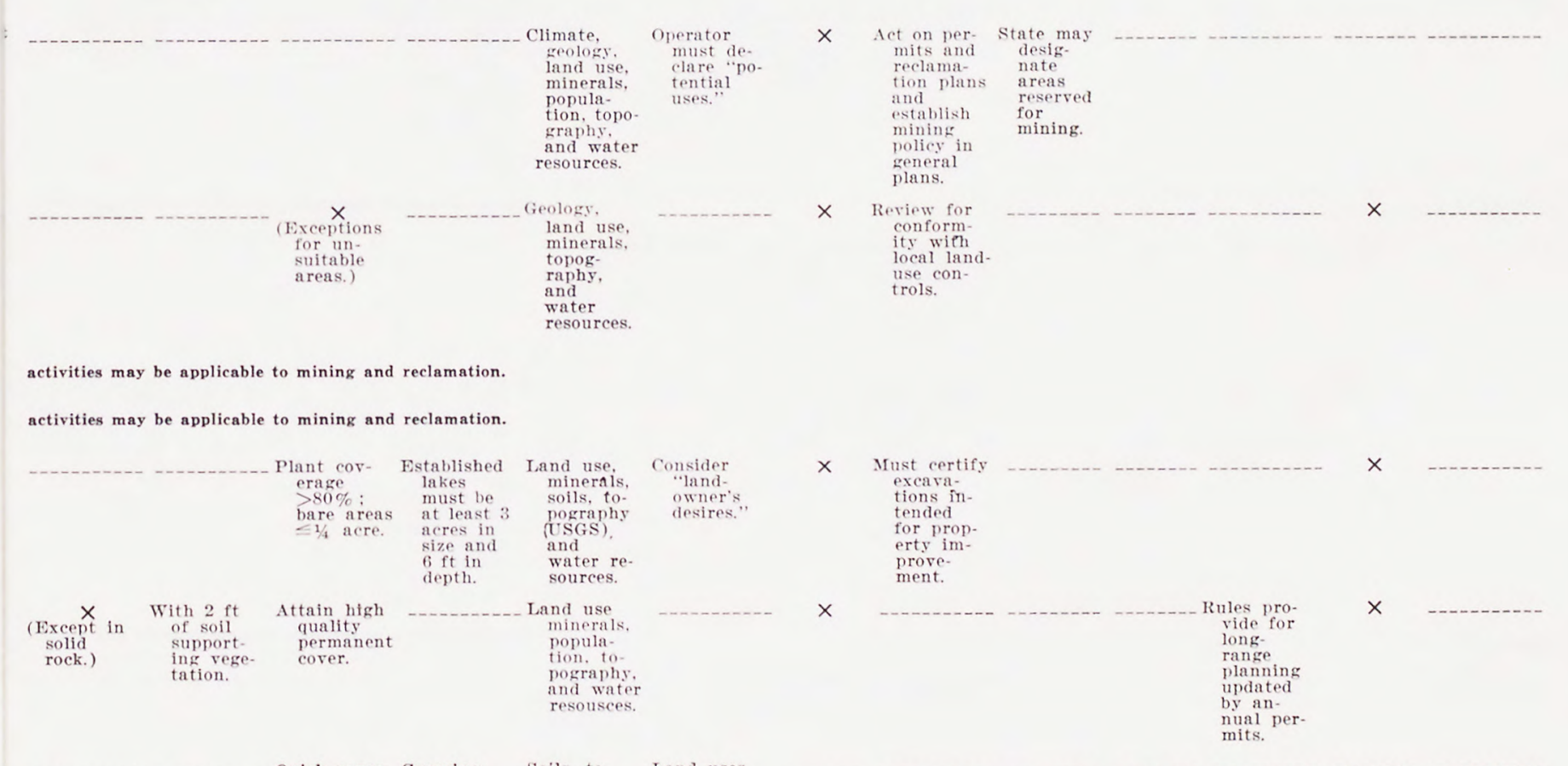

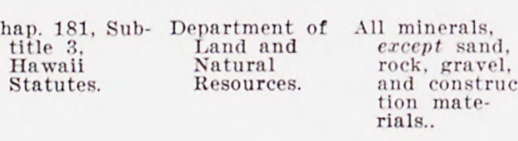

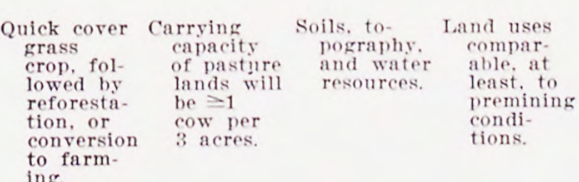

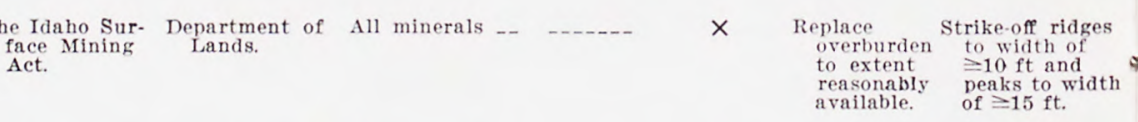

NOTE: Local governmental land-use controls and permit
NOTE: Local governmental land-use controls and permit

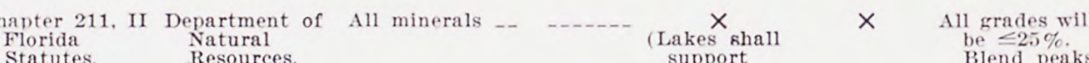

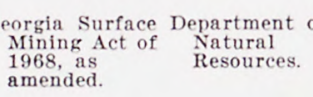

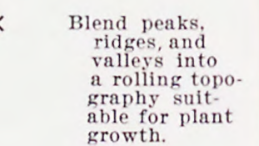

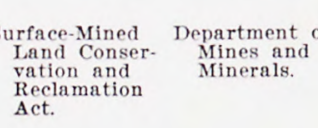

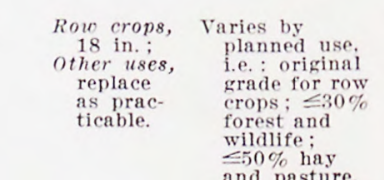

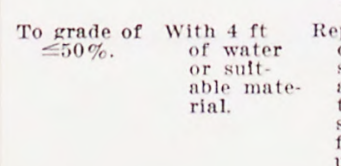

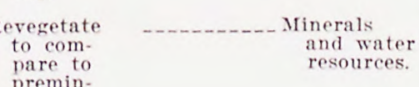

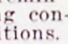

resources.

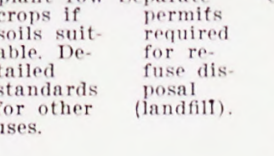

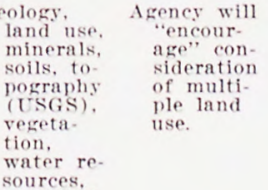

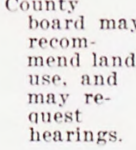


TABLE 1.-Matrix of information on state surface mined- area reclamation programs, December 1975-Continued

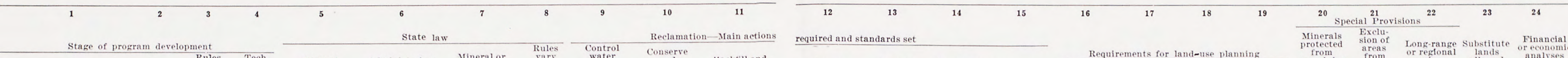

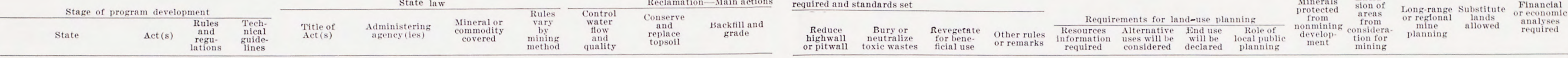

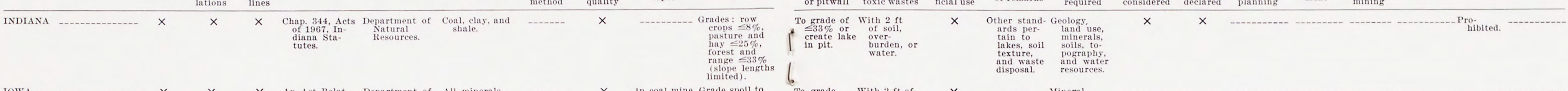

IOWA -..-

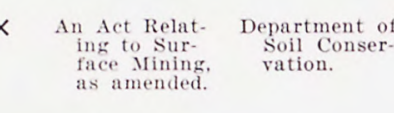

KANSAS

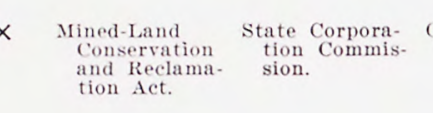

KENTUCKY -1- $\times$

LOUISIANA

MAINE

MARYLAND

(N)

Massachuset

MICHIGAN

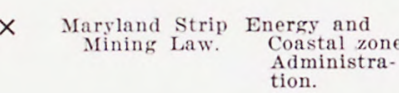

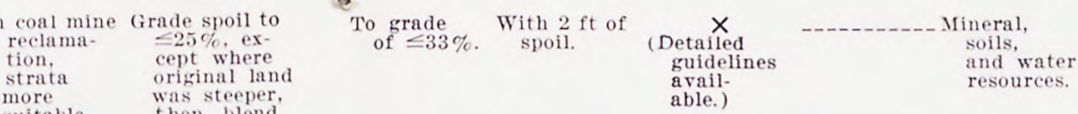

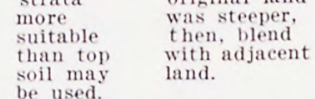

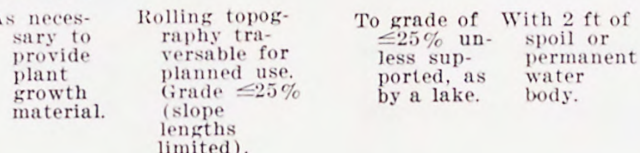

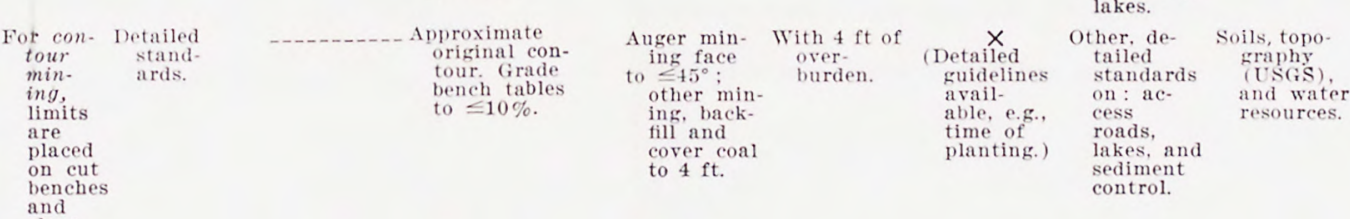

NOTE: Local governmental land-use controls and permit activities may be applicable to mining and reclamation.

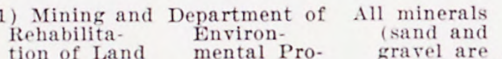

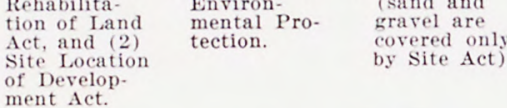

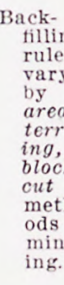

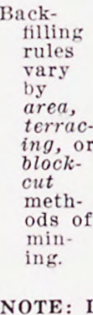

NOTE: Local governmental land-use controls and permit

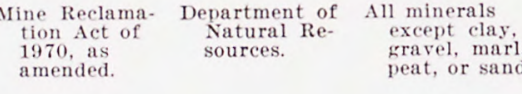

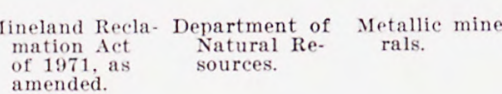

NOTE: Local governmental land-use controls and permit activities may be applicable to mining and reclamation

MISSISSIPPI

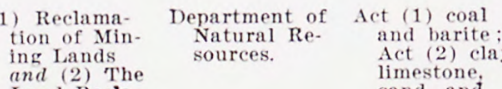

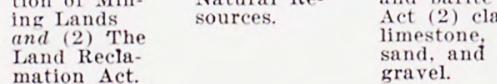 \\ MIISSOURI}

$$
\text { q }
$$

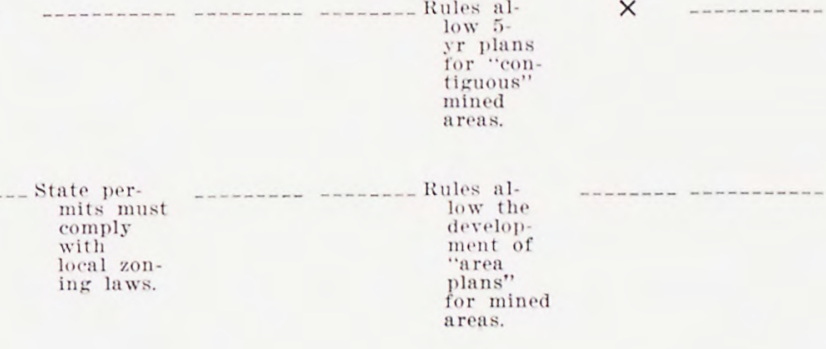

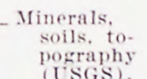

vegeta-
tion and
water re
sourres.

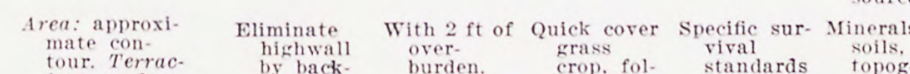

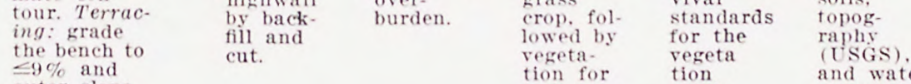

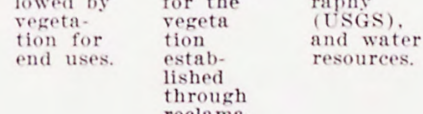

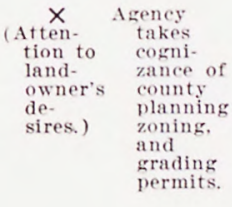

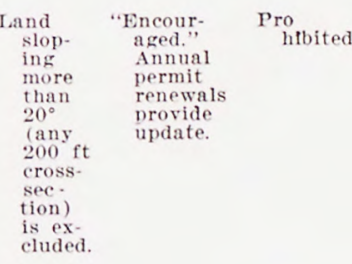

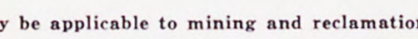

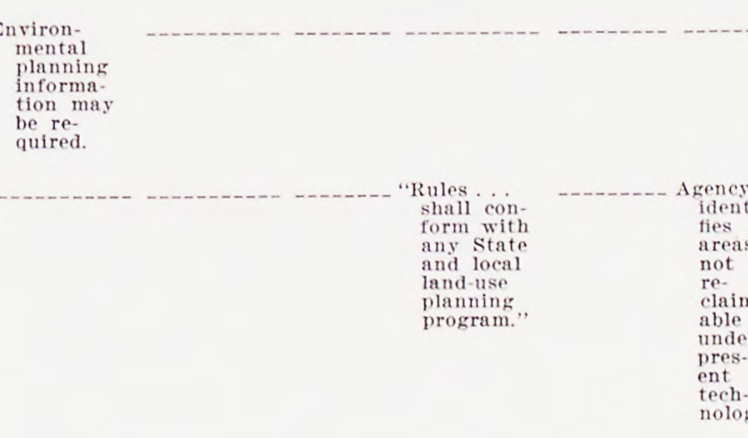

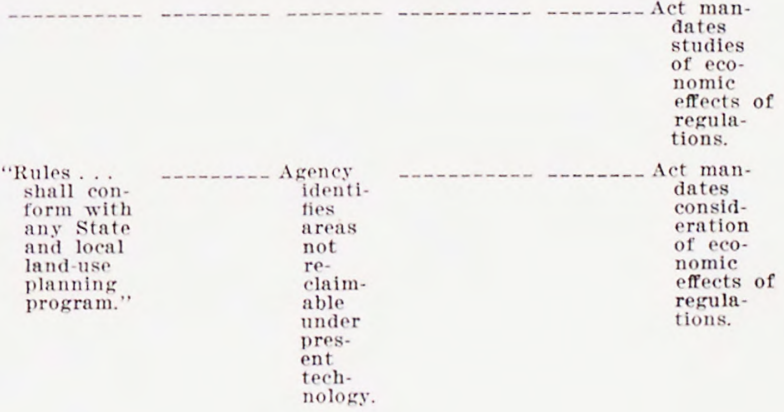

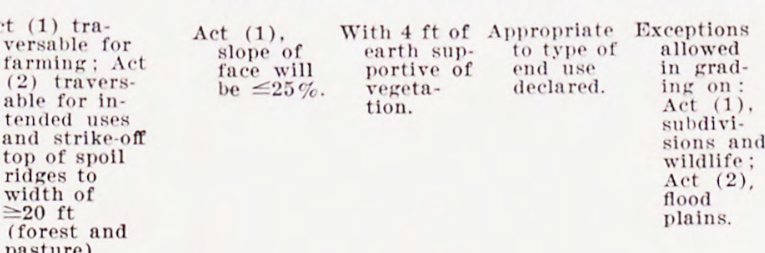




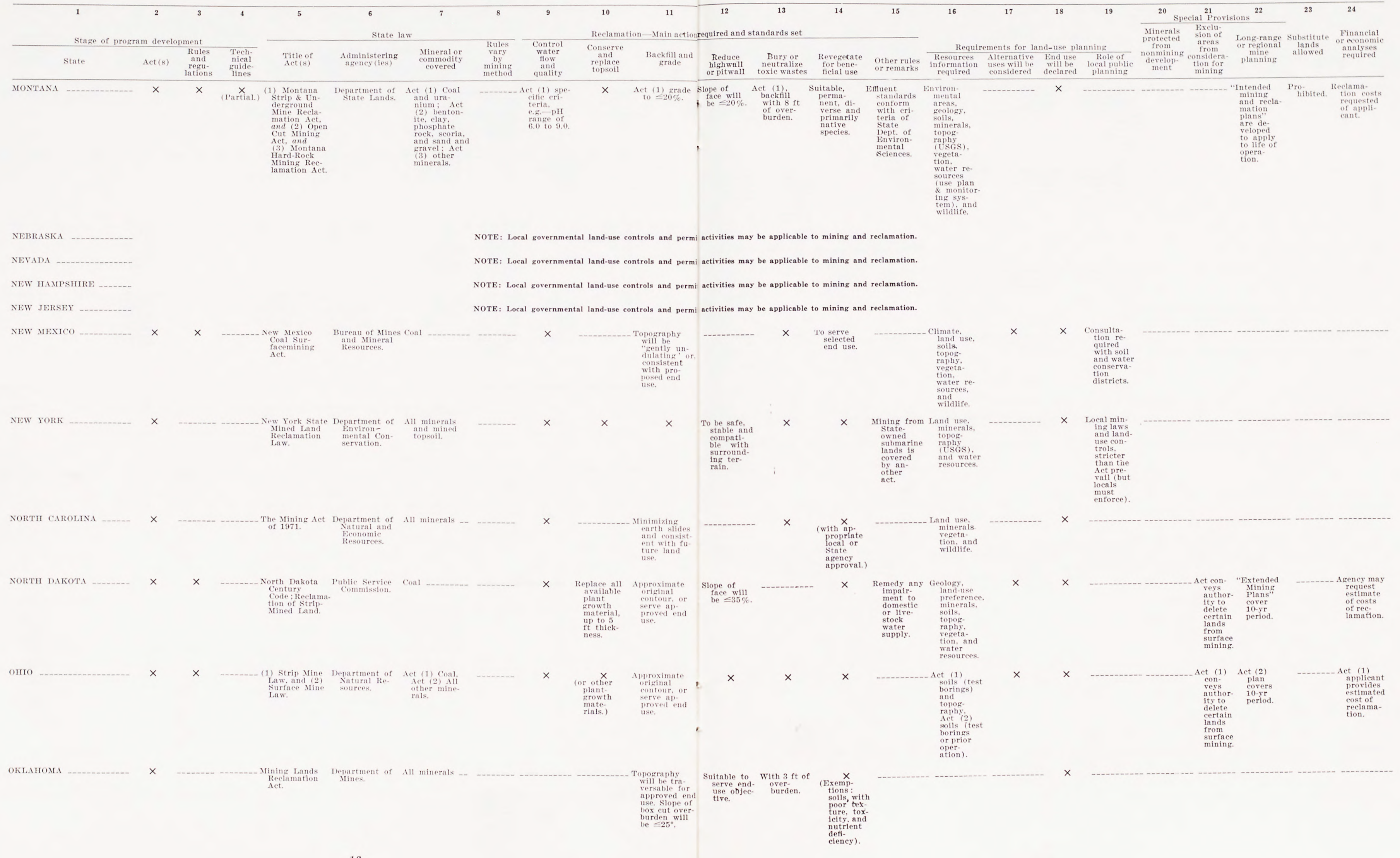




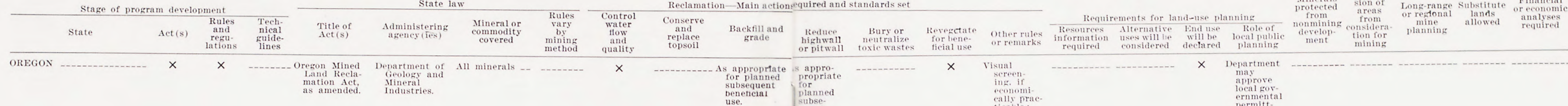

RHODE ISLAND -...--

SOUTH CAROLINA -...-

SOUTH DAKот

TEXAS

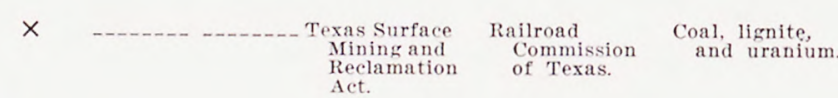

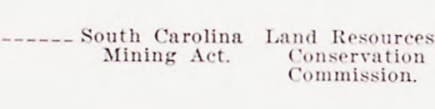

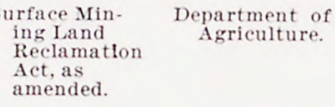

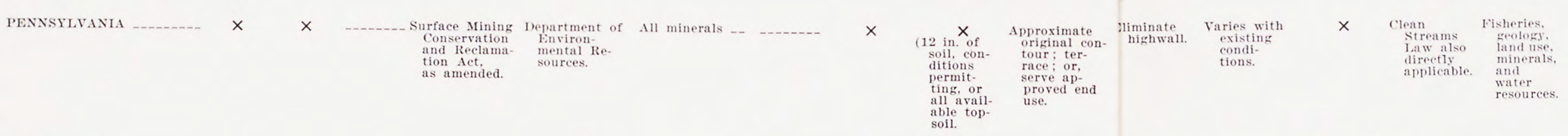

NOTE: Local governmental land-use controls and permititctivities may be applicable to mining and reclamation.

$$
\times \quad \times \quad \times \quad \begin{gathered}
\text { The Tennessee } \\
\text { Surface. Nin. } \\
\text { ing Act. }
\end{gathered}
$$

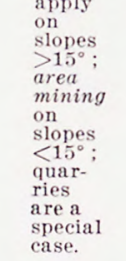

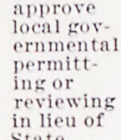

ing or
reviewing
in lieut of
state

NOTE: Local govern

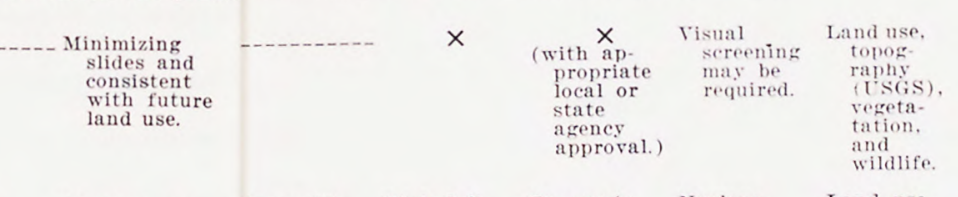

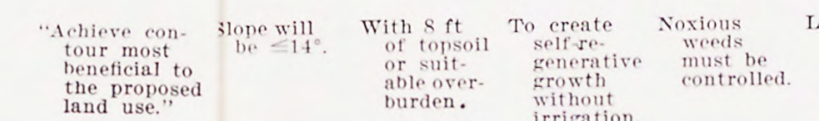

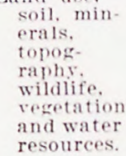

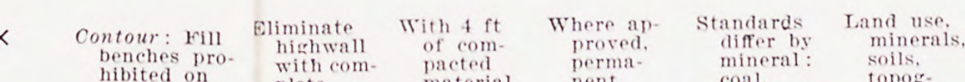

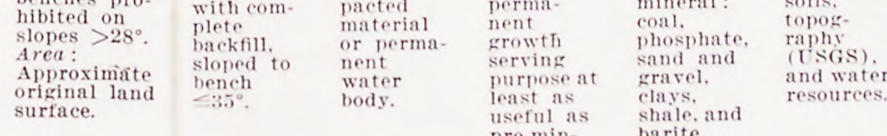

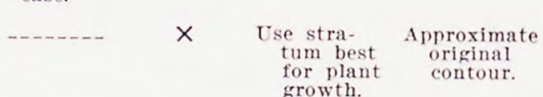

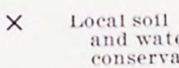

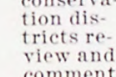

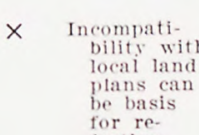

plans cil
be basis
for re
joction
joction

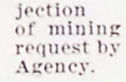

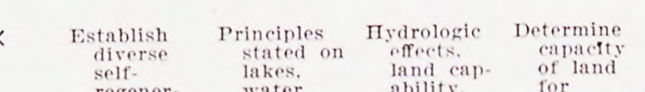

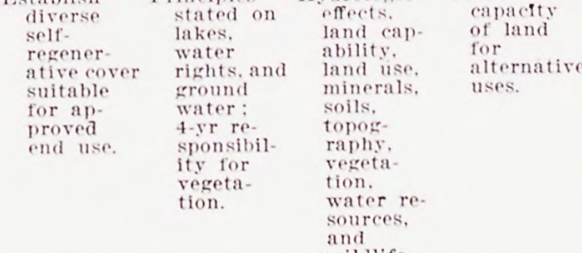
$\times$ Program is Land use.

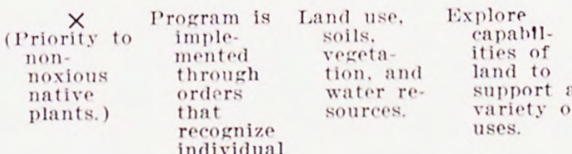

UTAH

VERMONT

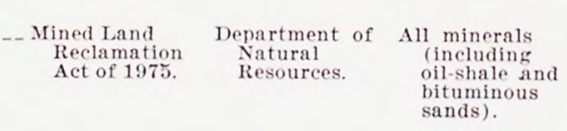
Wermont's Land
Useand
Development
Law.

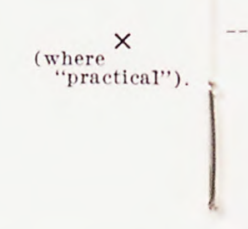

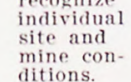

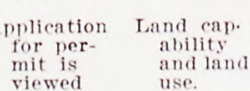

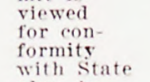

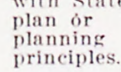
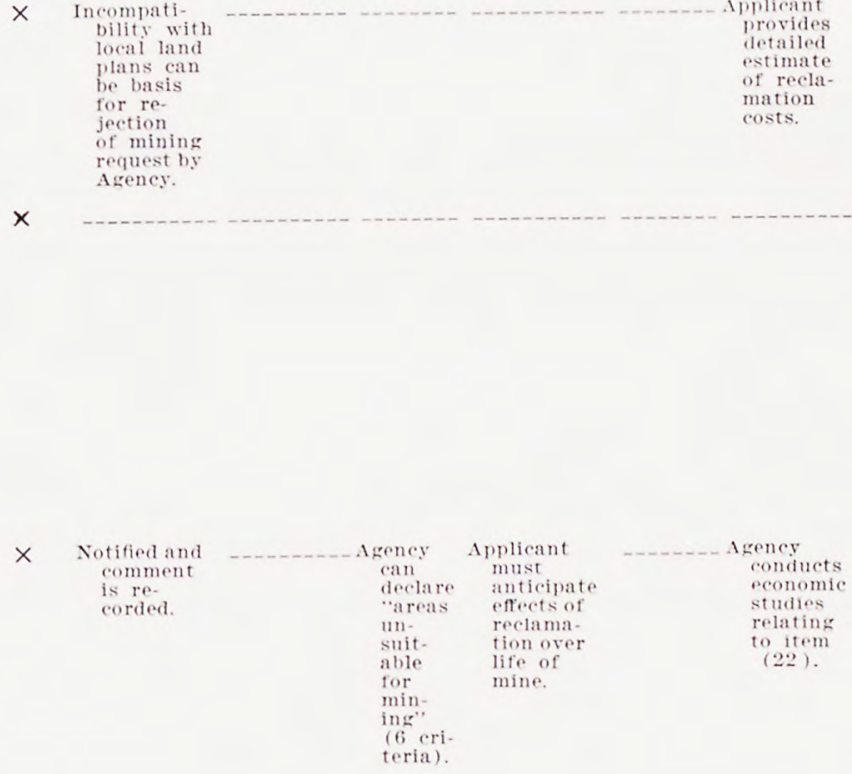

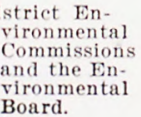


TABLE 1.-Watrix of information on state surface mined-area reclamation programs, December 1975-Continued

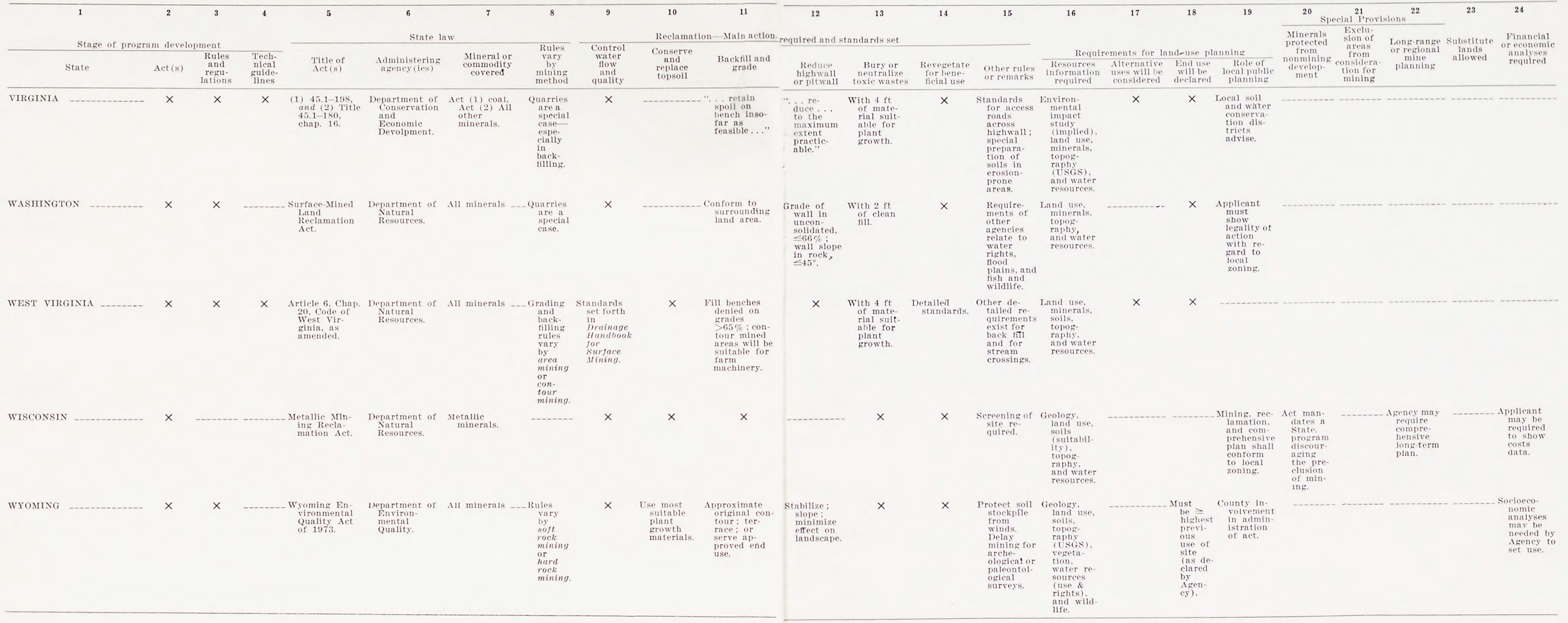


TABLE 2.- Hypothetical example of State and local controls and permits required for a surface mine 1

\begin{tabular}{|c|c|c|c|c|}
\hline Time period/activity & $\begin{array}{c}\text { Zon- } \\
\text { ing } \\
\text { and } \\
\text { re- } \\
\text { lated } \\
\text { local } \\
\text { land- } \\
\text { use } \\
\text { con- } \\
\text { trols }\end{array}$ & $\begin{array}{c}\text { State } \\
\text { recla- } \\
\text { ma- } \\
\text { tion } \\
\text { con- } \\
\text { trols }\end{array}$ & $\begin{array}{l}\text { Water, } \\
\text { air, } \\
\text { and } \\
\text { noise } \\
\text { pollu- } \\
\text { tion } \\
\text { con- } \\
\text { trols }\end{array}$ & $\begin{array}{l}\text { Other controls, } \\
\text { as named }\end{array}$ \\
\hline \multicolumn{5}{|l|}{$\begin{array}{c}\text { Pre-mining (years } 0-4) \text { : } \\
\text { Existing land use }\end{array}$} \\
\hline $\begin{array}{l}\text { Exospecting the area } \\
\text { Pros }\end{array}$ & X & $\bar{x}$ & $x$ & - n \\
\hline Mineral and economic evaluations & - & $\ddot{x}$ & -- & \\
\hline Acquisition of rights & -- & $x$ & - & State water rights. \\
\hline Surveying \& design of mine & -- & $\times$ & $\bar{x}$ & 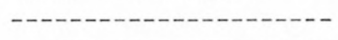 \\
\hline & -- & $\stackrel{x}{x}$ & $\times$ & 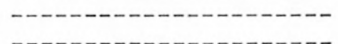 \\
\hline $\begin{array}{l}\text { Reclamation planning } \\
\text { End land-use planning }\end{array}$ & $\bar{x}$ & $\hat{x}$ & -- & 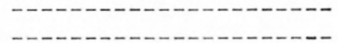 \\
\hline Costs analyses & $x$ & $\widehat{x}$ & $\bar{x}$ & $\begin{array}{l}\text { State and local environ- } \\
\text { mental controls. }\end{array}$ \\
\hline Obtaining mine permit ${ }^{2}$ & $x$ & $\times$ & -- & $\begin{array}{l}\text { Waste discharge } \\
\text { permits. }\end{array}$ \\
\hline Constructing roads and buildings ${ }^{2}$ & $x$ & $x$ & $\times$ & $\begin{array}{l}\text { State location of devel- } \\
\text { opment (e.g., as in } \\
\text { Maine). }\end{array}$ \\
\hline Obtaining utilities _- & $\times$ & -- & -- & $\begin{array}{l}\text { State utilities regula- } \\
\text { tion. }\end{array}$ \\
\hline Drainage and erosion control ${ }^{2}$ & & $x$ & $x$ & State water board. \\
\hline Fencing and screening ${ }^{2}$ & $\times$ & $x$ & $\bar{*}$ & State fish and game. \\
\hline $\begin{array}{l}\text { Environmental monitoring }{ }^{2} \\
\text { Joint mining and reclamation } \\
\quad(\text { years } 4 \text { to } 80) \text { : }\end{array}$ & -- & $x$ & $x$ & 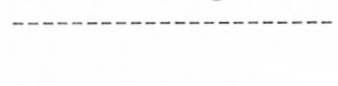 \\
\hline Removal and segregation of soils ${ }^{2}-$ & $x$ & $x$ & -- & $\begin{array}{l}\text { Local soil \& water } \\
\text { conservation. }\end{array}$ \\
\hline & $x$ & $x$ & $\times$ & Sanitary land fills. \\
\hline & $x$ & $x$ & $x$ & State permit. \\
\hline $\begin{array}{l}\text { Extracting and hauling minerals }{ }^{2}- \\
\text { Filling and grading }{ }^{2}\end{array}$ & $\underset{x}{x}$ & $\underset{x}{x}$ & $\underset{x}{x}$ & State severance taxes. \\
\hline $\begin{array}{l}\text { Fillng and grading } \\
\text { Reducing pitwalls or highwalls }{ }^{2}-\ldots\end{array}$ & $\begin{array}{l}x \\
x\end{array}$ & $\begin{array}{l}x \\
x\end{array}$ & $\begin{array}{l}x \\
x\end{array}$ & - \\
\hline Burying toxic materials ${ }^{2}$ & $x$ & $x$ & $x$ & 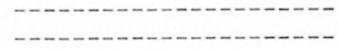 \\
\hline Revegetation $^{2}$ & -- & $x$ & -- & - n \\
\hline \multicolumn{5}{|l|}{ Post-mining (1 to 36 ): } \\
\hline Vegetation survival studies ${ }^{2}$ & -- & $\times$ & -- & State agriculture. \\
\hline $\begin{array}{l}\text { Pest and weed control }{ }^{2} \\
\text { Land capability studies }\end{array}$ & $\begin{array}{l}x \\
x\end{array}$ & $\begin{array}{l}x \\
x\end{array}$ & -- & $\begin{array}{l}\text { State agriculture. } \\
\text { State agriculture. }\end{array}$ \\
\hline Divesting ownership or rights & $\hat{x}$ & - & - & $\begin{array}{l}\text { Official acceptance of } \\
\text { lakes and roads. }\end{array}$ \\
\hline Water quality performance & $x$ & $x$ & $x$ & State agriculture. \\
\hline $\begin{array}{l}\text { Decommissioning mine (dismantling, } \\
\text { demolishing. etc). }\end{array}$ & $x$ & $x$ & -- & $\begin{array}{l}\text { State mine abandon- } \\
\text { ment laws. }\end{array}$ \\
\hline $\begin{array}{l}\text { Established end use } \\
\text { Recovery of bonds }\end{array}$ & $\stackrel{x}{x}$ & $\bar{x}$ & $\times$ & 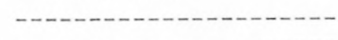 \\
\hline Recovery of bonds _...... & & & -- & 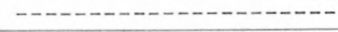 \\
\hline
\end{tabular}

1 Does not include controls pertaining to mine safety.
2 A process that tends to be maintained or repeated, as necessary, throughout much of the life ${ }^{2}$ A process 


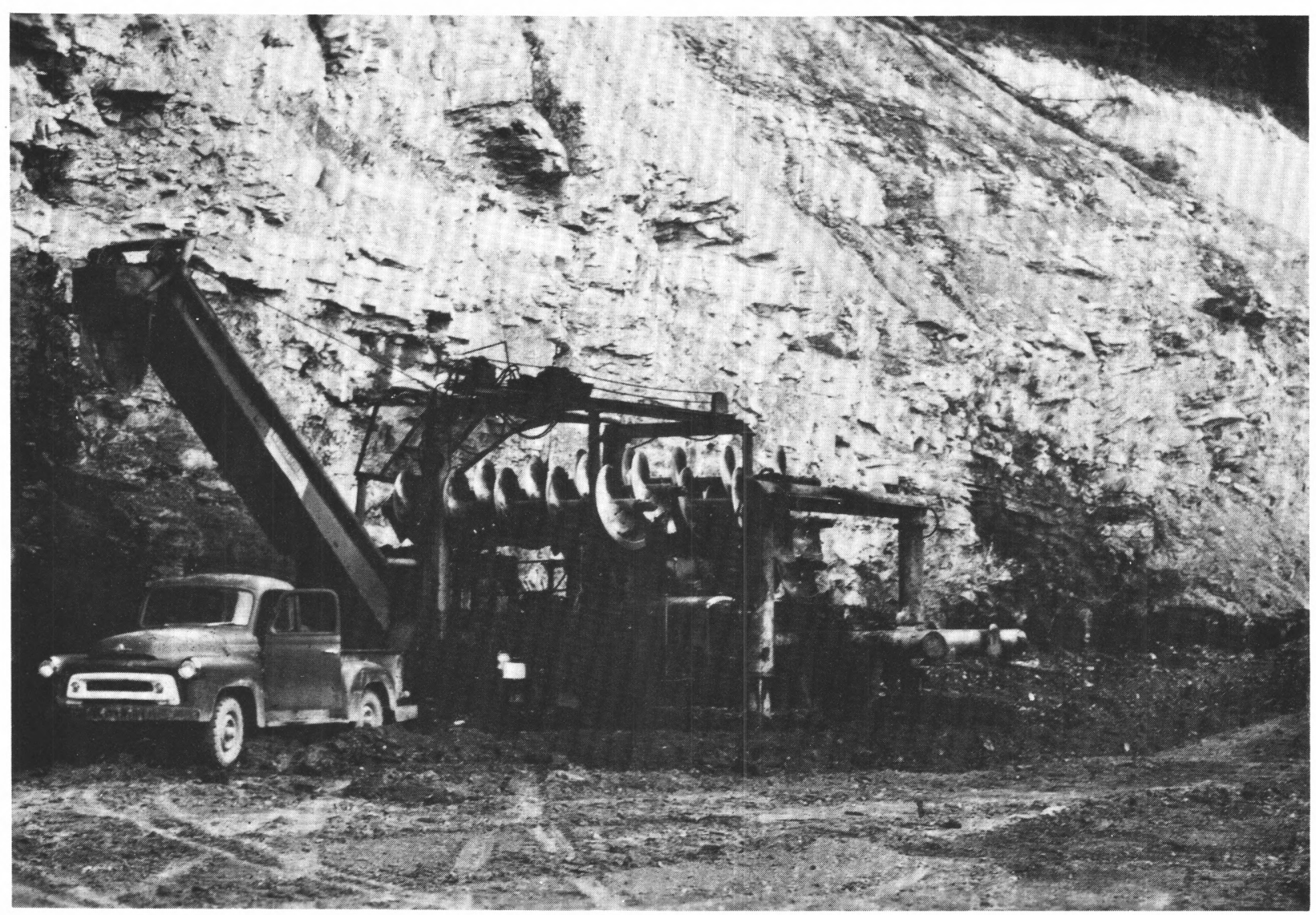

Figure 12.-Equipment used to drill laterally into a coalbed exposed in contour mining. Holes shown to the right of auger bits will be plugged, and the mined area will be covered with earth materials suitable for plant growth. (Photograph by West Virginia Department of Natural Resources, Division of Reclamation.)

\section{Column and heading Synonymous phrases}

(11) Backfill and grade Smooth and shape spoil. Fill pit and contour.

Terrace backfill.

Strike-off spoil.

(12) Reduce highwall or pitwall Smooth pitwalls.

Backfill highwall.

Knockdown cutface.

(13) Bury or neutralize toxic wastes

Cover mineral seam with clean fill.

Isolate and seal off toxic wastes.

(14) Revegetate for beneficial use _._Establish permanent and diverse plant growth. on spoils.

\section{Column and heading \\ Synonymous phrases \\ Seed, plant, and establish desired plant species.}

\section{COLUMNS 16-19, REQUIREMENTS FOR LAND- USE PLANNING}

Column headings 16,17 , and 18 refer primarily to mandates requiring the applicant to investigate, to analyze, to report, and to declare. Information is used to indicate a requirement for analytical information, rather than uninterpreted inventory data. Resource refers to a natural resources subject (for example, a study such as geology, or an activity such as land use). The term "Alternative Uses" takes the meaning commonly applied in land-use planning. The applicant is admonished to consider several possible long-term uses of the land to be reclaimed. This requirement differs from the practice common to some mined-area reclamation programs in which a list of acceptable end uses is presented to an applicant who then 


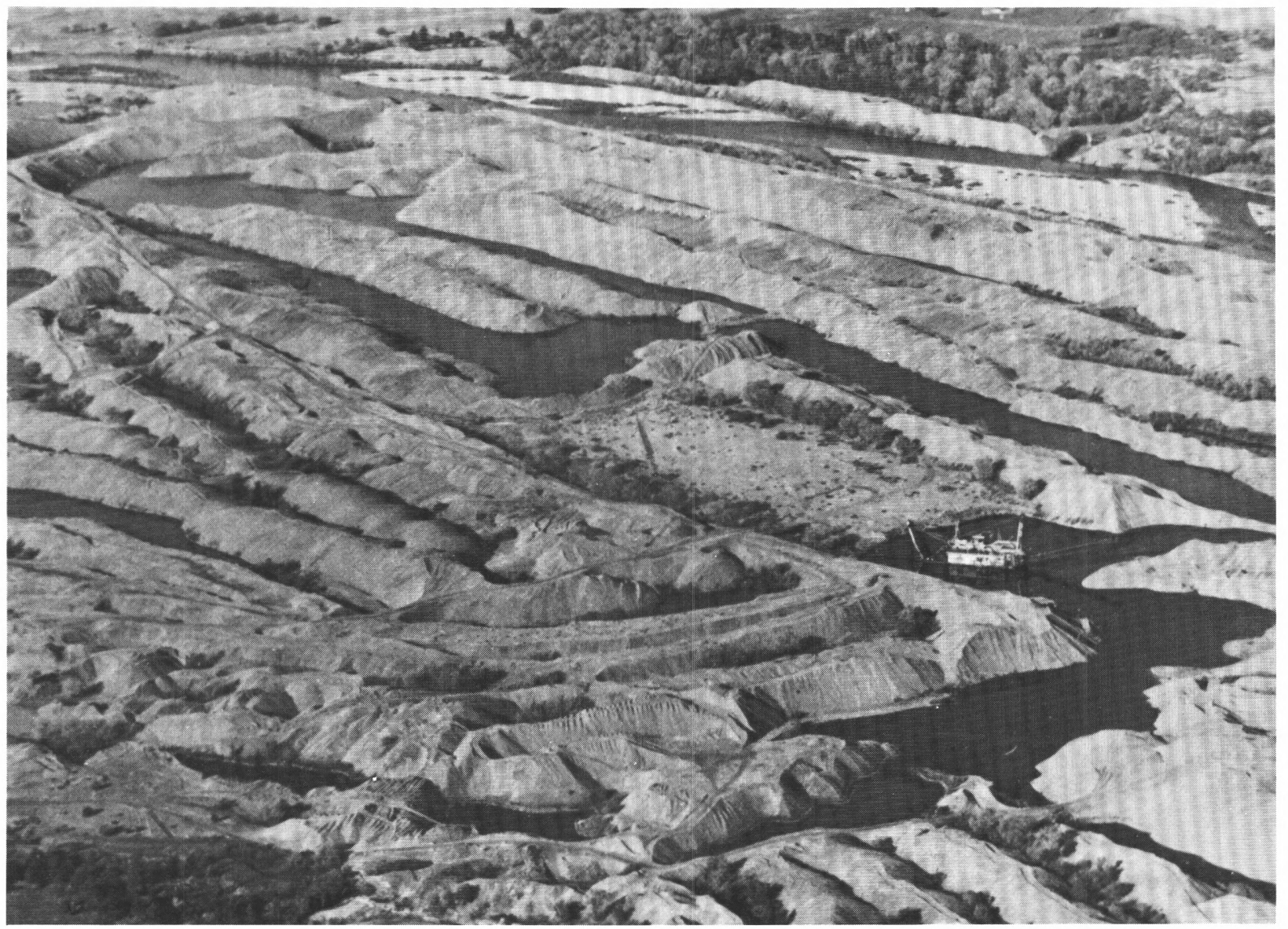

Figure 13.-Dredge mining for gold near Yuba City, California. (Photograph by Ward Sharrer, Sacramento Bee.)

may elect to propose an alternative to the uses on the given list. End Use Will Be Declared is a selfexplanatory term. In certain States, end use may also be called subsequent land use, beneficial land use, ultimate land use, and even after use. Role of Local Public Planning means the roles set forth, in the Act or regulations, for local units of government in the integrated process of mining, reclamation, and land use. It is important to note that this is a role that seems to be cast in the Act, whereas the actual role played by local public planning bodies in mined-area reclamation and related land use may be otherwise.

\section{COLUMNS 20-22, SPECIAL PROVISIONS}

The heading for column 20, Minerals Protected ..., shows the existence in the law of provisions that are, in effect, the other side of the coin of reclamation. This column provides a place to note programs that address not the reclamation of mined lands for multiple use but, instead, the protection of valuable mineral deposits from other land uses (for example, residential development) that tend to preclude mining. Exclusion of Areas from Consideration for Mining refers to a program provision that enables a State to deny any mining in certain carefully predetermined areas. Such a provision, it should be noted, is not to be confused with routine administrative denials of mining applications for inadequacies of information, infeasibility, or similar reasons. For example, the West Virginia agency has broad powers to deny applications. Long-Range . . . refers to an authorized time frame for reclamation and related planning that exceeds the usual $1-4$ year periods now required by most State rules and regulations. Regional ... refers to the geographic expansion of the planning boundaries from one mine site to two mines or more that are contiguous or in the same mining area. 


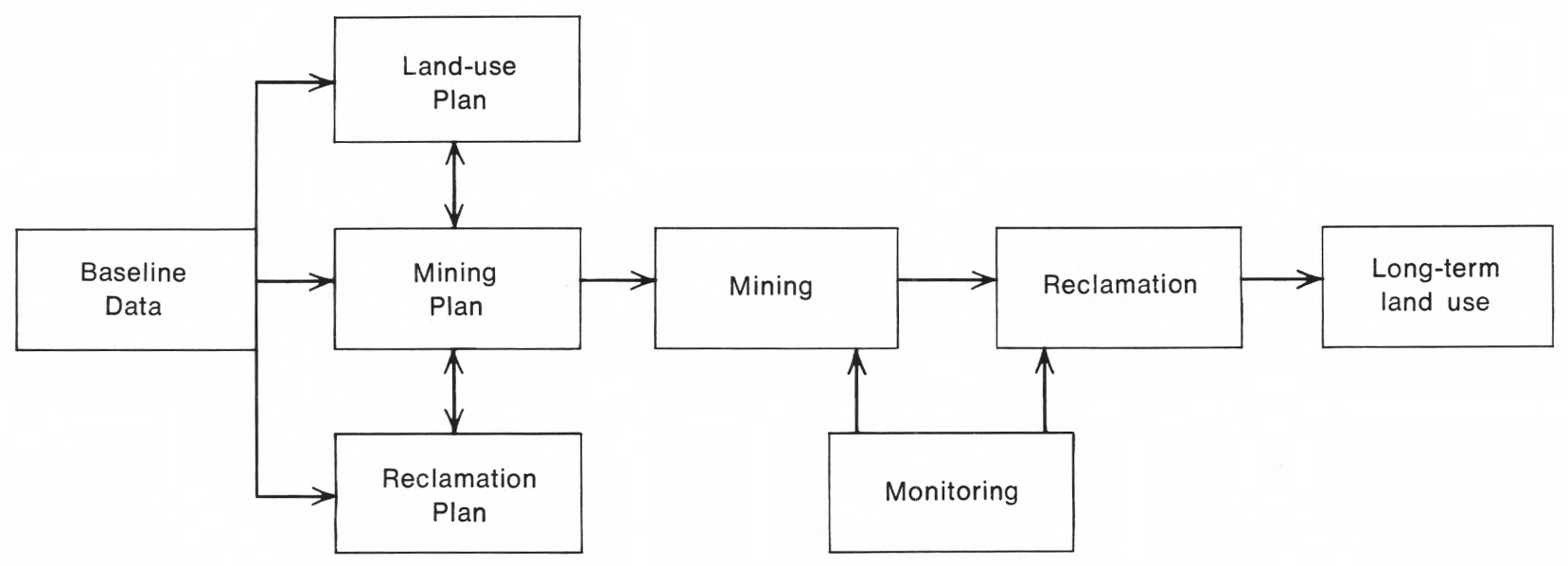

Figure 14.- Sketch of the concept of integrated mining, reclamation, and land-use planning.

COLUMN 23, SUBSTITUTE LANDS, AND COLUMN 24, FINANGIAL OR ECONOMIC ANALYSES

These headings treat miscellaneous categories. Planners should know that some States allow mine operators to reclaim selected lands, such as previously mined (orphan land) areas, in lieu of or as a substitute for reclamation at the active mine site. Financial refers to the requirement that the applicant estimate the costs of reclamation for the subsequent use of the regulatory agency in determining the size of the surety (performance) bond and the like. Economic, in column 24, refers to a statutory mandate requiring the regulatory agency to study and report on the effect of proposed rules and regulations on social and economic factors.

\section{THE STATE PROGRAMS: COMMON THREADS, DIFFERENCES, AND TRENDS}

The following analysis of the State mined-area programs is based on table 1, supplemental information accessible primarily in the various State statutes, rules and regulations, and guidelines. Several strong commonalities, many differences, and a few obvious trends characterize the State programs as a whole.

\section{STAGES OF DEVELOPMENT}

Mined-area programs tend to go through a process of becoming more sophisticated with time. For example, in 1975 California passed new legislation that is bereft of many specific requirements.
A similar situation prevails in other States which have not yet had sufficient time to promulgate rules and regulations, for example New York and Wisconsin. In contrast, a few of the States (e.g., West Virginia) have experienced many years of legislation and administration of a reclamation program, and the programs have become technically sophisticated.

Michigan is an example of a State in which the promulgation stage of program development has been delayed by legislative amendments (from 1971 to 1975 ).

The wording of the legislation of some States suggests that the promulgation of rules and regulations is permissible, not mandatory. Evidently, all States can issue orders and conduct certain licensing activities without rules and regulations. Nevertheless, in many States, there is a trend toward specificity in stating what is expected of the mine operator regarding the land during and after mining. States that have been involved in reclamation a comparatively long time have developed detailed standards that lay out mandatory steps and manuals that set forth recommended practice, or the state-of-the-art. Noteworthy manuals have been prepared by Iowa (undated), Kentucky (undated), Maryland (1975), and West Virginia (1975).

\section{THE PERMIT PROGESS}

The process of examining a mine operator's credentials and plans, and requiring a surety bond 
before a permit is given, has a common thread in all States. There are significant differences, however, in time aspects, in size of bonds, and particularly in the information requirements for licensing.

All State mined-area programs require that the applicant submit to the administering agency a notarized professional report that shows how and when the mining operation and accompanying reclamation will occur. The documents submitted are called "Master Plan for Extraction" in Colorado, "Mined Land Use Plan" in Georgia, "Mine and Rehabilitation Plan" in Iowa, or a number of similar terms. The number and designation of the permits that are issued may vary, also, but the effects are the same: an applicant is licensed to mine and to reclaim according to an agreed upon plan of scheduled, specifically located activities subject to inspection and periodic relicensing.

The following States require separate prospecting permits and related reclamation plans: Alabama, California, South Dakota, Texas, and Virginia.

\section{MINING METHOD}

Mining methods seem to be determined largely by economic, financial, and natural factors. Nevertheless, State mined-area reclamation programs are said by Skelly and Loy, Engineers and Consultants (1975) to have a significant impact on the mining method selected by the mine operator. Several States (e.g., Kentucky) set forth clearly the reclamation rules pertaining to different mining methods employed because of different natural factors in a given State. Many States are not so explicit in the printed rules and regulations, preferring instead to establish appropriate measures in the orders issued to an individual mine operator. A number of States have had little experience with surface mine regulation. In such States it is likely that reclamation rules and mining methods will reach a sort of "mutual accommodation" as actual experiences unfold.

\section{OVERRIDING OBJEGTIVES}

As indicated in table 1, State mined-area programs are not equivalent in terms of stage of development. But all the programs seem to be directed toward two interrelated objectives: (1) conversion of mined lands to planned productive use, and (2) minimization of deleterious effects stemming from the mine site. A review of rules and regulations and discussions with State reclamationists suggest that flexibility is sought in carrying out the reclamation program-but not at the expense of the objectives.

In practice, meeting the productive use objective might cause a land slope in Illinois "to violate" the basic grade and backfill standards-because planned use of the site for estate-type residences would be enhanced by leaving a steep slope and a mine cut filled with water. To hold rigidly to the restoration of land to the original contour (a common standard) could preclude, for example, the development of recreation and residential lakes in the flat lands of Kansas and Indiana. In practice, in specific instances, other common standards such as "restoral of native vegetation" and "replacement of topsoil" have proven to be inadvisable and have been replaced or amended by standards aimed at serving better the productive use objective.

The minimization of deleterious offsite effects is an underlying provision of State programs which, in the older programs, predates pollution control laws. State Reclamation Acts declare that the site will not be a source of siltation, of acidmine drainage, of noise pollution and will not constitute an eyesore. Hence, the adoption of rules requiring control of water flow and quality, neutralizing of toxic materials, erosion control, visual screening, and the explicit statement in State rules and regulations that State water quality criteria will be addressed and discharge standards will be met by the mine operator.

\section{THE DOGTRINE OF REASONABLENESS}

Inspection of the State laws and rules shows that the doctrine of being reasonable underlies most of the State mined-area programs. For example, in Idaho, the State-licensed mine operator must conserve and replace topsoil to the extent "reasonably available." " In Oregon visual screening with vegetation will be pursued "if economically practicable." 7

This doctrine of reasonableness tends to dissuade the State from asking for the physically impossible and from placing too heavy an economic burden on the mineral industries.

${ }^{6}$ Idaho Title 47, Chapter 15, Section 47-1509(7).

7 Oregon Statutes 517.790, Subsection (2) (f). 
FLEXIBLE INTERPRETATION OF STATE LAWS

In an analysis of surface mining and reclamation in 11 Midwestern States, Carter and others (1974) have shown that it is often the interpretation of the law rather than the law itself that dictates reclamation procedures. That study shows that although the reclamation requirements and the landscapes of adjoining States of Illinois and Indiana are similar, very different land-use patterns have emerged on reclaimed lands: 86 percent of Illinois permit lands ${ }^{8}$ were reclaimed for row crops and pasture, whereas 90 percent of Indiana permit lands were reclaimed for forest and range.

In revegetation, flexibility in interpretation of laws is being applied to the problems of revégetation of mined lands in arid climates. Much is yet to be learned about the time required for establishing plant growth and suitable species. Consequently, State standards applied to arid lands tend, presently, to be skeletal and may remain so until experience has demonstrated attainable conditions. In contrast, Iowa requires that revegetation be accomplished 24 months after the completion of mining, and Iowa provides detailed guidelines on the planting of desired species.

\section{ATTENTION GALLED TO OTHER LAWS}

A common characteristic of the State minedarea programs is the State's admonition to the mine operator applicant that other State and local licensing and permitting requirements are not necessarily satisfied in the approved reclamation program - that State waste discharge permits, State water rights, sanitary landfill requirements, local zoning permits, and the like must also be obtained. Several State mined-area programs require evidence of compliance with other applicable governmental requirements. With respect to land use, the long-term trend is clearly toward integrated mined-area licensing and local permitting (table 2).

\section{THE PLANNING PROCESS}

As used herein, the term "planning" refers to successive steps that, disregarding complexities, usually proceed as follows: (1) statement of objectives, (2) gathering of information and determination of factors critical to attainment of the objectives, (3) consideration and evaluation of

\footnotetext{
8 "Permit" lands are lands for which a State reclamation permit has been granted.
}

alternative means of meeting the objectives, and (4) selection and design of future actions-in amount, type, time, and place.

In general, all State mined-area regulatory agencies require the mine operator applicant to engage in a planning process. As manifest in State mined-area programs, the particular detail of the process that is actually applied varies from State to State.

Approaches to declaring the end-use or land-use objective vary by State and by age of program. Recent State legislation seems expansive in terms of requiring the mine operator applicant to look at "potential uses," as in California, or at "multiple land use," as in Illinois. Pre-1970 acts and regulations tend to accent attainment of the objectives of stabilizing slopes, preventing water pollution, and removing eyesores, by any reasonable method for any possible beneficial end use.

Present State programs tend to offer the applicant a "shopping list" of several potential land uses from which a specific end use will be chosen. Several States allow the applicant to propose a use that is not on the official list.

An analysis of recent State legislation and related rules indicates a trend toward stiffer requirements for information to support end-use choices, the evaluation of potential consequences, and the design and implementation of the mine-reclamation plan. The following phrases from State legislation suggest a need for high-quality analytical information :

[The application requirements . . . include . . .] "the anticipated hydrologic consequences of the mining operation"

"the capacity of the land to support its anticipated use following reclamation, including . . . the capacity of the reclaimed land to support alternatives uses" 10 ". . . current surface values and its [the land's] capabilities to support a variety of uses or proposed uses" 11

The general subject coverage of State information requirements is shown in column 16 of table 1. A comparison of columns 16,17 , and 18 suggests that a positive correlation exists between a State's requiring detailed baseline information consideration of alternative uses, and declaration of an end use.

${ }^{9}$ Texas Senate Bill 55, (1975), sec. 8 (3) (5).

10 "Texas Senate Bill 55, (1975), sec. $10(2)(3)$

11 Utah Rule M-3 (2) (a). 
The planning phase of mined area programs appears to be changing in two important respects. Time frames are being extended from the customary yearly licensing target to 5 years for contiguous mined areas (Kansas), to 10 years in "extended mining plans" (North Dakota), and even to the life of the mine (Montana). Also, State mined-area programs are being related increasingly to other planning programs, especially programs involving local government.

Roles for local planning bodies range from rather benign review activities to active participation in the licensing process. In the latter instance, private land-use objectives are scaled presumably against the declared public policy and adopted plans that pertain to the area. (See especially entries for California, Colorado, Illinois, Kentucky, Minnesota, South Dakota, and Wisconsin in column 19, table 1.) Provisions illustrative of a possible trend are quoted as follows:

\footnotetext{
"No permit shall be issued ... [where] surface mining would be incompatible with Federal, State, or local plans for land development . . ."12

". . . the mining and reclamation plan and the comprehensive plan [shall] conform with all applicable zoning ordinances . . ."
}

It is important to note that the Wisconsin Act is rather skeletal and not yet filled out with rules and regulations that amplify the comprehensive planning requirement to be placed upon the applicant mine operator. It is one thing to require coordination with, or conformity with, comprehensive planning, but quite another to require comprehensive planning by an applicant.

\section{CONCLUSIONS}

"The Utah legislature finds that: Reclamation requirements must be adapted to the diversity of topographic, chemical, climatic, biologic, geologic, economic, and social conditions in the areas where mining takes place." 14

1. State mined-area reclamation laws address a progression of private actions or initiatives which vary according to time, place, technology, and economic conditions. These laws function as "constraints" which affect the activities that occur before, during, and after mining.

\footnotetext{
12 South Dakota Century Code, Chapter 45-6A, as amended (1975).

3 Wisconsin, Chapter 318, sec. 144.85 (3) (d), Laws of 1973

${ }^{14}$ From sec. $2(3)$, H.B. No. 323, 1975. This bill became the Mined Land Reclamation Act of 1975 (Utah).
}

2. Surface mining-the principal means of providing the present needs of the United States for sand and gravel, clay, stone, phosphate, iron ore, copper ore, and coal -involves diverse methods of mining. The specific method applied at a given site is dependent on the site's physical characteristics and, increasingly, on reclamation requirements.

3. Techniques of reclamation are generally well advanced, but the presence of physical and temporal constraints still makes difficult the reclamation of certain types of mines. Mining and reclamation in arid and semiarid climates pose special problems of great complexity.

4. As of December 1975, mined-area reclamation programs which affect surface mining, associated reclamation, and subsequent land use of mined sites have been enacted by 38 States.

5. Most of the State mined-area programs have arisen since 1970, a fact which reflects: (1) A response to the "environmental movement," (2) increased competition for land use, and (3) increased surface mining activity as the "energy crisis" unfolded.

6. Differences in the details of State mined-area programs are common, as individual States face their own peculiar natural, economic, political, and social conditions.

7. Commonalities arise among many State reclamation programs, as similar conditions are recognized and as the accumulating mass of State experience is understood and adapted by new States coming on line.

8. Mined-area reclamation programs can be very sophisticated in terms of the regulatory approaches and the particular requirements placed on the mine operator applicant. As a general rule, in any given State, reclamation requirements are becoming progressively more comprehensive in coverage and more detailed in terms of definition through standards and guidelines.

9. There is a trend in the new State programs toward an integration of land use and 
mine planning, and toward requiring longer time frames and a more comprehensive approach to reclamation planning. State mined-area programs and advances in technology have already effected an integration of mine planning and reclamation planning.

10. All State mined-area reclamation laws recognize the possible role for local government in such activities as zoning; several of the mined-area programs require evidence of compliance with local planning controls. A few mined-area programs place local governments directly in the decisionmaking process with regard to the issuance of mining permits.

11. A great deal of high-quality information on natural resources is needed now and will continue to be required on a regular basis. Natural science monitoring is required if State mined-area reclamation mandates are to be adhered to and if the concept of integrated land use and mining for long-term beneficial use, private and public, is to be realized.

12. To serve the States, other interested units of government, and private parties, an efficient information system is needed for the recording and reporting of the status and content of State mined-area reclamation programs.

\section{REFERENCES CITED}

Angster, G. L., Hill, J. C., McBride, A. W., Paton, R. A., and Pope, H. H., 1970, Reclamation suggestions in planning for crushed stone quarry operations to facilitate the integration of abandoned quarry sites into the urban fabric: Durham, N.C., Nello T. Teer Co., $43 \mathrm{p}$.

Bisselle, A., Binder, A., Holberger, R., Morrow, L., Pagano, R., Parker, D., Sasfy, S., and Strieter, R., 1975, An approach to environmental assessment with application to western coal development: McLean,
Va., MITRE Corporation Rept. [No.] 6988, p. IV-22IV-23, prepared for Resource and Land Investigations (RALI) Program.

Bituminous Coal Research, Inc., 1974, Glossary of surface mining and reclamation technology: Washington, D.C., National Coal Association, 25 p.

Carter, R. P., LaFevers, J. R., Corke, E. J., Kennedy, A. S., and Zellmer, S. D., 1974, Surface mined land in the Midwest (U.S.) - a regional perspective for reclamation planning: Argonne National Laboratory report to U.S. Bureau of Mines, $678 \mathrm{p}$.

Grant, M. J., 1973, Rhode Island's ocean sands-management guidelines for sand and gravel extraction in State waters: Kingston, University of Rhode Island, The Coastal Resources Center, Marine Technology Rept. 10, $51 \mathrm{p}$.

Iowa Land Rehabilitation Board, [undated], Recommendations for establishment of vegetation on surface mined areas: Des Moines, Iowa, Department of Soil Conservation, Division of Mines and Minerals, $20 \mathrm{p}$.

Kentucky Department for Natural Resources and Environmental Protection, [undated], Engineer's handbook on strip mining in Eastern Kentucky: Frankfort, Kentucky, Division of Reclamation, $60 \mathrm{p}$.

Maryland Land Reclamation Committee, 1975, Guidelines manual for surface coal mine operators (revised): Maryland Dept. of Energy and Coastal Zone Administration, Bureau of Mines, 31 p., appendices.

Matter, F. S., Clark, K. N., Hann, J. A., Schuman, S., and Blanchard, B. J., 1974, A balanced approach to resource extraction and creative land development: Tucson, University of Arizona, Colleges of Agriculture and Mines, $85 \mathrm{p}$.

Paone, James, Moring, J. L., Giorgetti, Leo, 1974, Land utilization and reclamation in the mining industry, 1930-71: Washington, D.C., U.S. Bureau of Mines, IC $8642,61 \mathrm{p}$.

Skelly and Loy, Engineers and Consultants, 1975, Economic engineering analysis of U.S. surface coal mines and effective land reclamation: Washington, D.C., U.S. Bureau of Mines Contract Rept. SO 241049, 595 p.

West Virginia Department of Natural Resources, 1975, Drainage handbook for surface mining (revised): Charleston, W. Va., Division of Reclamation, 75 p., appendices.

Zube, E. H., 1963, Taconite and the landscape, Lake Superior South Shore Area: Madison, Wisconsin Department of Resource Development, $47 \mathrm{p}$. 


\section{A DIRECTORY TO STATE SOURCES OF INFORMATION ON SURFACE MINED-AREA RECLAMATION PROGRAMS, 1975}

State

Alabama

Alaska

Arizona

Arkansas

California

Colorado

Connecticut

Delaware

Florida

Georgia

Hawaii

Idaho
Agency

Strip-mining Section Division of Safety and Inspection

Department of Industrial Relations

Division of Lands

Department of

Natural Resources

Arizona State Land

Department

Department of Pollution Control and Ecology

Bureau of Mines and Geology

Department of Conservation

Reclamation Section Department of

Natural Resources

The Natural Resources Center

Department of Environmental Protection

Division of Environmental Control

Department of Natural Resources and Environmental Control

Bureau of Geology

Division of

Resource

Management

Department of

Natural Resources

Land Reclamation Section

Division of

Environmental

Protection

Department of

Natural Resources

Department of Land and Natural Resources

Division of Earth Resources

Department of Lands
Individual

Location

H. T. Williams, Chief of Safety and

Inspection

1816 8th Ave., North Birmingham, AL 35203 205-251-1181

Michael Smith, Director, and

Pedro Denton, Minerals Officer

323 E. Fourth Ave. Anchorage, AK 99501 907-279-5577

Andrew L. Bettwy, Commissioner

1624 W. Adams St. Phoenix, AZ 85007 602-271-4621

S. Ladd Davies, Director

Milton Bonner, Geologist

8001 National Drive Little Rock, AR 72209 501-371-1701

Robert Streitz, Advanced Planning Officer

1416 Ninth St.

Room 1341

Sacramento, CA 95841 916-445-0514

Director

c/o Division of Mines 1845 Sherman St. Denver, CO 80203 303-892-3401

Hugo Thomas, Director

165 Capitol Ave. Room 561

Hartford, CN 06115 203-566-3540

N. C. Vasuki, Director

Dover, DL 19901 302-678-4764

Charles Hendry, Chief Steve Windham,

Deputy Chief

903 W. Tennessee St. Tallahassee, FL 32304 904-488-4191 or 3636

Sanford Darby, Chief

P.O. Box 4845

Macon, GA 31208 912-744-3346

Christopher Cobb, Chairman and Member, Board of Land and Natural Box 621 Honolulu, HI 96809 808-548-6550

Terry Maley, Director, Statehouse, Room 120 Norman Day,

Boise, ID 83720

Supervisor, Conser- 208-384-3280 vation Section 


\section{A DIRECTORY TO STATE SOURCES OF INFORMATION ON SURFACE MINED-AREA RECLAMATION PROGRAMS, 1975-Continued}

state

Illinois

Iowa

Kansas

Kentucky

Louisiana

Maine

Maryland

Massachusetts

Michigan

Minnesota

Mississippi

Missouri
Agency

Division of Land Reclamation

Department of Mines and Minerals

Division of Reclamation

Department of Natural Resources

Division of Mines and Minerals

Department of Soil Conservation

Mined-Land Conservation and Reclamation Board

State Corporation Commission

Division of Reclamation

Department for Natural Resources and Environmental Protection

Department of Conservation

Bureau of Land Quality Control

Department of

Environmental

Protection

State Bureau of Mines Maryland Energy and Coastal Zone

Administration

Department of Public Works

Geological Survey Division

Department of Natural Resources

Division of Minerals

Department of Natural Resources

Mississippi Geological, Economic and Topographical Survey

Office of Land Reclamation

Department of Natural Resources
Individual

Eugene Filer, Supervisor, and

Charles Medvick, Resource Planner

Richard McNabb, Director

Marvin B. Ross, Mine Inspector

G. T. V.an Bebber, Chairman,

and

Charels F. Bredahl, Member

Kenneth Ratliff, Director

Ray Sutton, Commissioner

Henry Warren, Director

Harry Buckley, Director

Joseph Sinnott, State Geologist

R. Thomas Segall, Geologist in Charge

Elwood Rafn, Director Paul Pojar (Staff)

William H. Moore, Director

Location

State Office Bldg.

Room 704

Springfield, IL 62706

217-782-4970

618-993-5450

613 State Office Bldg. 100 N. Senate Ave.

Indianapolis, IN 46204 317-633-6217

Grimes State Office Building Des Moines, IA 50319 515-281-5774

Fourth Floor State Office Bldg.

Topeka, KS 66612 913-296-3325 or 3600

5th Floor, Capitol

Plaza Tower

Frankfort, KY 40601 502-564-6940

P.O. Box 44275

Capitol Station

Baton Rouge, LA 70804

504-389-5161

State House

Augusta, ME 04330

207-289-2111

City Building

Westernport, MD

21562

301-359-3057

100 Nashua Street

Room 805

Boston, MA 02114

617-727-6398

Stevens T. Mason

Bldg.

Lansing, MI 48926

517-373-1256

Centennial Office Bldg.

St. Paul, MN 55155

612-296-4810

P.O. Box 4915

Jackson, MS 39216

601-354-7011

Robert Neuenschwander, Director

P.O. Box 1368

Jefferson City, MO

65101

314-751-2357 


\section{A DIRECTORY TO STATE SOURCES OF INFORMATION ON SURFACE MINED-AREA RECLAMATION PROGRAMS, 1975-Continued}

State

Montana

Nebraska

Nevada

New Hampshire

New Jersey

New Mexico

New York

North Carolina

North Dakota

Ohio

Oklahoma

Oregon

Pennsylvania
Agency

Division of Reclamation Department of State Lands

Office of State

Planning and

Programming

Nevada Bureau of

Mines and Geology Management,

Bureau of Geology and Topography Division of Natural Resourees

Bureau of Mines and Mineral Resources

Bureau of Minerals Department of Environmental Conservation

Land Quality Section Division of Environmental Management Department of Natural and Economic Resources

Division of Reclamation Public Service Commission

Division of Reclamation

Department of Natural Resources

Department of Mines

Mined Land Reclamation Office

Department of Geology and Mineral Industries

Bureau of Surface Mine Reclamation Department of Environmental Resources illiam Dubois, Inspector of Mines

Sargent Goodhue, Chief of Forest and

C. C. McCall, Administrator

W. Don Nelson, Director

Glenn Stewart, State Geologist

Location

Capitol Station

Helena, MT 59601

406-587-2074

P.O. Box 94601

Lincoln, NE 68509

402-471-2414

University of Nevada

Reno, NV 89507

702-885-5243

Statehouse Annex

P.O. Box 856

Concord, NH 03301

603-271-3456

James Hall

University of New

Hampshire

Durham, NH 03824

603-862-1216

Dr. Kemble Widmer, State Geologist

John Fitch Plaza

P.O. Box 1889,

Room 709

Trenton, NJ 08625

609-292-2576

Frank E. Kottlowski, Director

Campus Station

Socorro, NM 87801 505-835-5420

Richard Arieda, Assistant Director

50 Wolf Road

Albany, NY 12233

518-457-7480

Craig McKenzie, Chief

P.O. Box 27687

Raleigh, NC 27611

919-829-4740

Ed Englerth, Chief,

Capitol Bldg.

and

Allen D. Klein

Bismark, ND 58501

701-224-2410

Ken Faulk, Chief (Acting)

Fountain Square

Columbus, OH 43224

614-466-4850

Ward Padgett, Chief Mines Inspector

253 Capitol Bldg. Oklahoma City, OK 73105

405-521-3859

Standley Ausmus,

P.O. Box 1028 Administrator,

Albany, OR 97321 and

503-928-5386

P.O. Box 2063

William Guckert, Director

Harrisburg, PA 17120

Ralph V. Zampogna,

717-787-5103 


\section{A DIRECTORY TO STATE SOURCES OF INFORMATION ON SURFACE MINED-AREA RECLAMATION PROGRAMS, 1975-Continued}

State

Rhode Island

South Carolina

South Dakota

Tennessee

Texas

Utah

Vermont

Virginia

Washington

West Virginia

Wyoming
Agency

Statewide Planning Program

Department of Mining and Reclamation

Land Resources

Conservation

Commission

Division of Conservation

Department of

Agriculture

Division of Surafce Mining and Land Reclamation

Department of Conservation

Division of Surface Mining and Reclamation

Railroad Commission of Texas

Division of Oil and Gas Conservation

Department of Natural Resources

Agency of Environmental Conservation

Murray Wood,
Director,
and
Jack S. Whisnant,
Geologist

Al Griffiths, Director

Chase Delony,

Director,

and

Individual

Location

Daniel W. Varin Director

George Laughlin

Roy D. Payne, Director,

and

J. Randel Hill

Cleon B. Feight, Director.

and

Ron Daniels, Mined Land Coordinator

Martin L. Johnson, The Secretary, and

Edward Koenemann, Director, Division of Planning

Division of Mined Land Reclamation Department of Conservation and Economic Development

Division of Geology and Earth Resources

Department of Natural Resources

Division of Reclamation

Department of Natural Resources

Grant Hollett, Reclamation Specialist, and

William D. Roller, Director

\section{Donald Ford,} Geologist

Benjamin G. Greene, Chief

Floyd Stautz, Director Box 450

Zoning

Department of

Natural Resources

Division of Land Quality

Department of Environmental Quality
No. 3

Room 322

Charleston, WV

25305

304-345-3267

Madison, WI 53701

608-266-8034

265 Melrose St

P.O. Box 11708

Columbia, SC 29211

Joe Foss Bldg.

Room 110

(2) 57501

2611 W. End Ave.

ashville, TN 37203

Capitol Station

O. Drawer 12967

ustin, TX 78711

1588 W. N. Temple 84116

State Office Bldg.

Montpelier, VT 05602 802-826-3357

Drawer U

Big Stone Gap, VA

(210

Public Lands Bldg.

206-753-6183

State Office Bldg. W Cheyenne, WY 82002 307-777-7756 



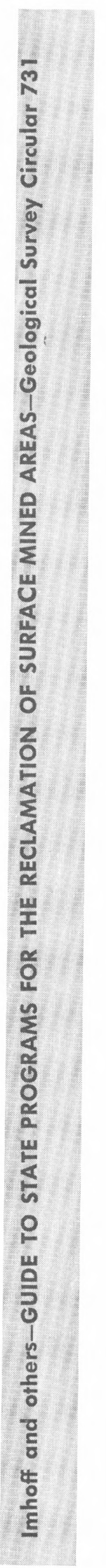

